\title{
Molecular biology interventions for activity improvement and production of industrial enzymes
}

\author{
Shashi Kant Bhatia ${ }^{a, b}$, Narisetty Vivek ${ }^{c}$, Vinod Kumar ${ }^{c}$, Neha Chandel ${ }^{d}$, Meenu Thakur ${ }^{\mathrm{e}}$,Dinesh

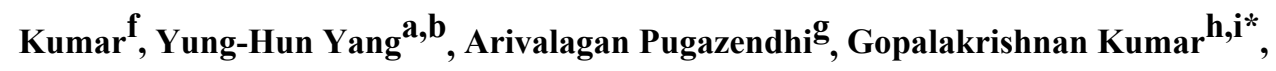

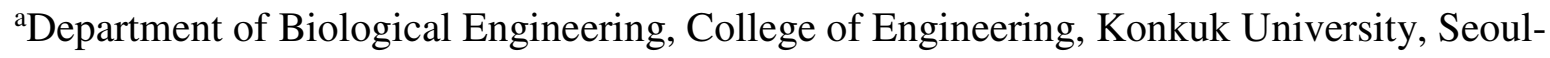
05029, Republic of Korea

${ }^{\mathrm{b}}$ Institute for Ubiquitous Information Technology and Application, Konkuk University, Seoul-05029, Republic of Korea

${ }^{\mathrm{c} C e n t r e}$ for Climate and Environmental Protection, School of Water, Energy and Environment, Cranfield University, Cranfield MK43 OAL, UK

${ }^{\mathrm{d} S}$ School of Medical and Allied Sciences, GD Goenka University, Gurugram-122103, Haryana, India

e Department of Biotechnology, Shoolini Institute of Life Sciences and Business Management. Solan-173229, Himachal Pradesh, India

${ }^{\mathrm{f}}$ School of Bioengineering \& Food Technology, Shoolini University of Biotechnology and Management Sciences, Solan-173229, Himachal Pradesh, India gTon Duc Thang University, Vietnam

${ }^{\mathrm{h}}$ Institute of Chemistry, Bioscience and Environmental Engineering, Faculty of Science and Technology, University of Stavanger, Box 8600 Forus, 4036 Stavanger, Norway ${ }^{i}$ School of Civil and Environmental Engineering, Yonsei University, Seoul, 03722, Republic of Korea

* Corresponding authors: E-mail: gopalakrishnanchml@gmail.com (G. Kumar) 


\begin{abstract}
Metagenomics and directed evolution technology have brought a revolution in search of novel enzymes from extreme environment and improvement of existing enzymes and tuning them towards certain desired properties. Using advanced tools of molecular biology i.e. next generation sequencing, site directed mutagenesis, fusion protein, surface display etc. now researchers can engineer enzymes for improved activity, stability, and substrate specificity to meet the industrial demand. Although many enzymatic processes have been developed up to industrial scale, still there is need to overcome limitations of maintaining activity during catalytic process. In this article recent developments in enzymes industrial applications and advancements in metabolic engineering approaches to improve enzymes efficacy and production are reviewed.
\end{abstract}

Keywords: Enzyme; cosmetic; pharmaceutical; metagenomics; directed evolution; fusion protein 


\section{Introduction}

With the revolution in the chemical industry, there is a new challenge to extend microbes and enzymes based chemical synthesis processes (Hazeena et al., 2019; Rajesh et al., 2019). For a transition from a petrochemical-based industry to a green chemistry-based economy, we must ensure that our ability to explore novel enzymes, engineer biocatalysts, and design artificial enzymes does not become a bottleneck. There is an enzyme for each natural compound and these enzymes also have capability to catalyze nonnatural chemical reactions (Sheldon \& Pereira, 2017). Further, these enzymes are evolving continuously in vivo to metabolize new unnatural chemicals. Various applications of enzymes have been reported in many industries such as the food and beverage industry (amylase, lipase, pectinase), textile and leather industry (laccase, cutinase, protease), cosmetic industry (superoxide dismutase (SOD), oxidase), pharmaceutical (chitinase, streptokinase), chemical industry (epimerase, lipase), etc. (Moreno et al., 2020; Patel et al., 2019; Raveendran et al., 2018). Enzymes carry out the reactions under ambient temperatures, pressures, physiological $\mathrm{pH}$, in aqueous solutions as well as in organic solvents (Bollinger et al., 2020). Further, enzyme-mediated reactions do not require any additional steps for either activation or reactivation of surface functional groups in the active sites (Wang et al., 2016). But with every process comes the limitations to be addressed; these enzymes are often selective in nature, enantioselective to specific substrates, and are not in favourable condition with non-natural substrates (Arnold, 2018). Few of the industrial processes do require catalysts that could withstand extreme temperatures and pressures, but these enzymes lose their specific activity at those conditions resulting in lower end-product yield and productivity (Hammer et al., 2017). Sometimes enzymes isolated from the natural resources or in their native form do not have desired properties which enforce researchers to search for novel enzymes. Nowadays metagenomics is routinely practiced for microbial taxonomy and finding novel enzymes (Kumar Awasthi et 
al., 2020). Recently many enzymes have been discovered from diverse habitats such as endoglucanase from termite gut (Guerrero et al., 2020), $\alpha$-amylase from sheep rumen (Motahar et al., 2020), esterase from lotus pond sludge (Qiu et al., 2020), etc. using a metagenomic approach. With the advancements of genetic engineering technology genes from uncultured, pathogenic, and slow growing microbes can be cloned into genetically recognised as safe (GRAS) microbes for higher production (Sharma et al., 2019). Despite of exploration of different habitats for novel enzymes still, their industrial applications are hampered by low activity, stability, and specificity. To overcome these limitations a variety of engineering approaches such as directed evolution, fusion protein, surface display, the introduction of unnatural amino acids have been applied to improve enzymes (Emond et al., 2020; Guirimand et al., 2019a). Information generated on the basis of gene sequence, structure-function relationship, enabling researchers to design new enzymes having novel function (Mayer et al., 2019).

In the present scenario, enzymes are an important part of our routine life and many industrial applications. With the advancements in biotechnology and molecular biology tools, researchers have capability to engineer and design new enzymes having improved and novel functions. The main objectives of this article are to provide an updated view on industrial applications of various enzymes and different molecular biology approaches to search for new enzymes and improve the existing ones for increased activity, and stability.

\section{Industrial applications of enzymes}

From ancient times microbes and enzymes are used in food processing and preparation of beverages (Far et al., 2020). During the last few decades, applications of various enzymes extended to various sectors such as food and feed, textile \& leather processing, cosmetic, pharmaceutical, and bioenergy sectors (Table 1) (Raveendran et al., 2018). All this is possible 
due to advances in technologies involved in microbial cultivation, throughput screening, and microbial fermentation technologies. A greater share of the enzyme is produced utilizing microorganisms (bacteria and fungi) due to their rapid growth, minimum nutrient requirements and easy to culture at a large scale. Almost $75 \%$ of the enzyme market is covered by hydrolases (protease, lipase, amylase, cellulases) and their demand is increasing continuously (Jemli et al., 2016). In the food industry enzymes are mostly used to perform hydrolytic reactions to improve solubility and clarification (Mahmoodi et al., 2017). Recent trends in the food industry include the development of functional food (prebiotics and probiotics) and artificial sweetener etc. (Choi et al., 2015). In the textile industry the fibres require different processing steps such as seizing, bleaching, dying, and functionalization. These all steps are energy intensive and require various chemicals. Enzymes are getting interest in the textile field and can be used to perform a function such as desizing, wrinkle proof, and improve other properties (Duarte et al., 2020; Wang et al., 2018). In the cosmetic industry a variety of chemicals are used and produced from petrochemical based material. Nowadays consumers are looking for cosmetic products based on natural compounds, so companies are now looking for various enzymes have cosmetic related applications. The use of various enzymes such as superoxide dismutase (Li et al.), protease, and lipase, etc. have been explored for cosmetic related applications (Gomes et al., 2020).

With the introduction of advanced technologies such as sequencing, metagenomics, site directed mutagenesis, fusion protein, bioinformatics, and computational tools it is become possible to improve the existing enzymes and design new enzymes that have novel properties. These advancements in enzyme research shifting the enzyme market towards other sectors such as the synthesis of chiral molecules (amino acids, amino alcohols, and amines) required for pharmaceutical purposes. The utilization of enzymes in the synthesis of 
various pharmaceutical important compounds are already reviewed and discussed (Choi et al., 2015). Energy demand is increasing continuously, and overexploitation of fossil-based resources will lead to the depletion of these energy resources in the next few decades. There is a need to find alternate sources of energy that are sustainable, renewable, and eco-friendly. Lignocellulose is the abundantly used raw material and can be utilized as raw material for microbial fermentation to produce biofuel. Various enzymes such as cellulases, hemicellulases, laccases, lignin peroxidases, are used to pre-treat and hydrolyse lignocellulosic biomass into free sugars (Østby et al., 2020). Other enzymes like carbonic anhydrase, fatty acids decarboxylase are also used in the energy sector to produced advanced biofuels (Bhatia et al., 2019; Jiang et al., 2019).

\section{Molecular biology approaches for improved enzyme production}

Enzymes as biocatalysts are used in almost all industrial sectors to fasten the rate of biological and chemical reactions. Microorganisms are considered the best source of enzymes as these can be easily cultivated at much faster rates in fermenters and thus are the preferred choice for mass production of industrial enzymes. Also, microorganisms have been isolated from the widest ecosystems and extreme environments - hot springs, cold glaciers, and ice bergs, high pressure, acid mine drainages, hypersaline environments (Mirete et al., 2016). These microbes have evolved and adapted themselves to extreme conditions and are known to produce extremozymes - which may be well suited for industrial processes (Bhatia et al., 2020a). Enzymes having unique properties can be isolated from uncultured microbes using a metagenomics approach. Alternatively, we can modify or engineer the existing enzymes to enhance their utility for commercial applications using various molecular biology techniques such as directed evolution promoter screening, engineering of translation and transcription factors, codon optimization and protein fusion, etc. 


\subsection{Metagenomics and genome mining for novel enzymes}

Metagenomics, also known as population genomics, community genomics, and environmental genomics, is the study of genome structures of microbial communities present in diverse environmental conditions. This technique eliminates the need of culturing the microbe using conventional culture techniques and makes use of direct sequencing techniques, to identify the gene of interest. Environmental samples are directly used to isolate gDNA and create metagenomic libraries, in suitable vectors. Depending on the insert size, several options have been explored. These include plasmids, cosmids, fosmids, Bacterial Artificial Chromosomes (Thimoteo et al.), $\lambda$ phage (Madhavan et al., 2017). The vectors are further transformed into suitable expression systems - Escherichia coli, Bacillus subtilis, Pseudomonas, and other eukaryotes (Lorenz \& Eck, 2005). This process allows the mining of new enzymes avoiding the problems associated with non-culturable microbes through sequence based and functional based screening. Sequence based metagenomics involves sequencing of DNA from environmental samples, genome assembly, gene identification, a search of the complete metabolic pathway, and compare organisms of different communities. With the advent of next generation sequencing (NGS) it is possible to generate a large amount of data in a fraction of the cost as compared to traditional sequencing technologies (i.e., Sanger) (Koutsandreas et al., 2019). NGS and advanced computational tools allow to analyse a large set of sequencing data, but annotation of genes totally relies on sequence similarity of the already characterized genes in the public database. Due to this limitation, almost $40-50 \%$ of genes in the genome are routinely reported as hypothetical. In functional metagenomics, metagenome libraries are screened for the desired protein function. Metagenomics is not able to distinguish the active member from the inactive member of the microbiome community. To improve enzyme screening and selection process it is suggested that samples should be analysed by integrating metagenomics with other omics techniques 
such as meta-transcriptomics and meta-proteomics etc. Using metatranscriptomics i.e. RNA sequencing (RNASeq) of expressed transcripts within a microbiome at a time point under a set of environmental conditions, actively expressed proteins can be easily screened (Shakya et al., 2019). In the metaproteomics approach, the entire protein content of environmental microbiota at a given point in time is analysed. The use of metaproteomics for the analysis of extracellular proteins from natural environmental samples is a complicated task as these proteins cannot be easily and reproducibly separated and concentrated from the extracellular matrix (Speda et al., 2017). Because of this issue majority of metaproteomics studies are performed for the study of the intracellular fraction of metaproteome. Bioinformatics analysis is further used for sequence analysis, Pfam analysis, structure prediction, and understand its phylogeny (Prayogo et al., 2020).

Several cellulases, proteases, lipases, $\alpha$-amylase, chitinase, $\beta$-glucosidase, and endoglucanses have been isolated from extreme environmental conditions, using a metagenomic approach and patented (Prayogo et al., 2020). Such enzymes have shown much better thermostability and thus are better suited for industrial applications. Identifying and choosing the unique environments and niches, is the most important step for the successful identification of novel enzymes, with improved properties. Innumerable examples of such intelligent screens are available in the literature. Metagenomic libraries obtained from mangrove sediments have successfully been used to isolate proteases, enzymes commercially used in the food industry, and bioremediation processes. Candidate PR4A3, an alkaline metalloprotease enzyme, has demonstrated high thermotolerance and thermostability. It has shown promising results for biotechnological applications (Pessoa et al., 2017).

Cellulases are widely used in biofuel production, detergent, paper, and cotton industry. Thermostable cellulases have been isolated from the cellulose rich environment of the bamboo paper pulp industry (Prayogo et al., 2020). Metagenomic cellulases have also 
been isolated from diverse niches like soil, animal and insect microbiomes, faeces, and compost samples (Tiwari et al., 2018). Lipases are other important enzymes, widely used in food, detergents, paper, and pharmaceutical industries. Metagenomics has proved an effective tool for mining of lipases from uncultured microflora (Almeida et al., 2019; Tang et al., 2017). These metagenomic lipases - LipS, LipG9 and LipR1 have shown promising enantioselectivity for resolution of alcohols, carboxylic acids, esters from racemic mixtures, biodiesel ester, and flavour ester synthesis (Almeida et al., 2019). Amine transaminases (ATAs) have particularly emerged as valuable biocatalyst for the production of drug intermediates and stereoselective chemical compounds like sitagliptin, dilevalol, formoterolo, and mexiletine (Koszelewski et al., 2009; Savile et al., 2010). A limited number of ATAs has conventionally been isolated from bacterial and fungal strains, after repeated rounds of directed evolution. These enzymes require tremendous improvement in properties like thermostability, stability in organic solvents, and storage, for industrial applications. Metagenomes from hot springs of China, Italy, and Iceland, have yielded three thermostable ATAs (Ferrandi et al., 2017). Thermotolerant $\Omega$-TA has also been isolated from metagenomes isolated from hypersaline environments of Triassic salt mines. These novel enzymes have adapted to halophilic conditions with better stability in organic solvents (Kelly et al., 2019). Xylanases, isolated from mesophilic fungi Trichoderma ressei, have found usage in wide industries ranging from the food and feed industry, paper and pulp industry, bioethanol, and biofuel production. But these enzymes have lower stability at high industrial temperatures. Thermostable xylanases, with higher activity compared to $T$. ressei xylanase have been isolated from metagenomes derived from lignocelluloses enriched composts (EllilÃ et al., 2019). Furthermore, 25 families of thioesterases have been identified to play active role biocatalysis of protein, lipids, and aromatic compounds metabolism. Metagenomic approach has been used by the researchers to isolate novel thioesterases belonging to family 
13, from activated sludge samples, which play important role in biocatalysis of phenylacetic acid and 4-chlorobenzene, both compounds associated with environmental pollution (Sanchez-Reyez et al., 2017).

The efficiency of the strategies can be improved by using specific enrichment techniques or using high through-put screening systems (Lorenz \& Eck, 2005). The simpler screening techniques make use of chromogenic and fluorogenic substrates like methylumbelliferyl (MU)-glycoside substrates, for identifying the activity of enzymes. Another approach makes use of substrates with self immolative linkers, specifically for screening of unsaturated glucuronidases (Nasseri et al., 2018). Substrate induced gene expression screening (SIGEX), which contains GFP as a reporter gene is another interesting approach to identify novel enzymes from metagenomic libraries. It is based on the fact that the expression of GFP is induced by the production of certain metabolites (Madhavan et al., 2017). Recent advances in the use of ultra-high thoroughput screens (uHTS) can be further explored to increase the speed of novel enzyme discovery from metagenome libraries. Traditional agar-based screenings can be replaced by 96-well microtitre plate (MTP) assays to quickly screen numerous chromogenic and fluorogenic substrates, thus decreasing the screening time of metagenomes. Genetic selection systems based on either gain of function or loss of function strategies, are one such complex examples of uHTS. These methods have successfully been employed for the isolation of novel $\beta$-galactosidases and vitamin biosynthesis genes (Cai et al., 2018). Droplet and flow cytometry based sorting of metagenomes has also been used to screen large biosynthetic clusters, which can further be sequenced (Markel et al., 2019). Despite all these studies, bioprospecting for novel enzymes still remains a challenge. Choosing the unique environments, appropriate sampling of the environmental samples followed by smart screening techniques is a prerequisite for the success of the metagenomics approach. 


\subsection{Engineering for enhanced enzyme production}

A quest for novel enzymes, with optimum properties for industrial usage, can be further accentuated by using metabolic engineering approaches. Genetic material contains all the information which decides its structure, function, secretion, and regulation. Thus, strategies involving modifications of genetic structures have been proved as an effective tool to enhance their production.

\subsubsection{Promoter optimization}

A very first approach for engineering for enhanced enzyme production can be at the level of a promoter. The promoter region provides the site for RNA polymerase to bind and initiate the transcription. A strong constitutively expressing promoter with high affinity must be ideal for large scale production of biotechnological products (Qin et al., 2011). Breakthrough in sequencing methods and bioinformatics tools has provided data for the screening of new promoters, in non-model organisms. This approach has been used to identify new promoters in Clostridium thermocellum, a promising candidate for the production of ethanol. Promoters 2638 and 815 were found to have higher activity for reporter genes (Olson et al., 2015). Promoter engineering is the need of the hour. This can be achieved either by mutagenesis, engineering of native promoters or by screening for the strong synthetic promoters. Random mutation inside the inulase promoter and signal peptide of Kluyveromyces marxianus has shown to improve the secretion of lignocellulolytic enzymes (Zhou et al., 2018). Alternatively, a strong promoter can be cloned along with the gene of interest, to increase its production. Cbh1 is considered as a strong promoter and employed to overexpress the gene of cellobiohydrolase II (cbhII) to increase its production in T. ressei (Fang \& Xia, 2013). In another study, the production of cellulases has been improved in S. cerevisiae, by placing the native SOD1 and PSE1 under pgkl promoter (Kroukamp et al., 2013). Rational engineering approaches have also provided good results. kasOp* is one such example of engineered 
promoters from Streptomyces coelicolor. This promoter has been modified in two steps, by removing the binding site of its two regulators ScbR2 and ScbR (Wang et al., 2013).

$\mathrm{P}_{\mathrm{GAP}}$ is one most commonly used promoter used for heterologous protein expression in P. pastoris (Zhang et al., 2009). It has been used for the constitutive expression of lipases in high cell density conditions (Wang et al., 2012). Efforts have been made to further improve it by generating its promoter library using Error prone PCR. These mutants provided many folds increased expression, which can further be explored for engineering interventions (Qin et al., 2011).

\subsubsection{Increased expression by transcription regulation}

The fine interplay between activators, inducers, and repressors molecule in any organism, is responsible for the regulation of biosynthetic pathways, at the transcription level. Transcription factors are required for the expression and production of enzymes. CLR4 is for example one such conserved regulator for the production of cellulases in Neurosopra crassa and Myceliophthora thermophila (Liu et al., 2019). Overexpressing the transcription factors has been used as an effective strategy to increase the expression of target genes in $S$. cerevisiae (Alazi et al., 2018; Chua et al., 2006). The same phenomenon has also been observed in T. Ressei and A. oryzae. Overexpression of XlnR, a transcriptional activator of cellulolytic genes in A. oryzae has been shown the levels of hydrolytic enzymes (Noguchi et al., 2009). Genetic modification of Xyr1, has been utilised as a promising strategy to increase the production of cellulase, cellobiosidase and $\beta$-D-glucosidase in T. Ressei (Jiang et al., 2016). The production of several important enzymes, in presence of substrates like glucose has been shown to be regulated by creA mediated carbon catabolite repressor, thus requiring presence of inducers in culture conditions to produce them (Niu et al., 2015).

Few interesting studies have successfully shown inducer independent hyper production of enzymes like cellulases. This has been achieved by overexpression of 
transcription regulator $\mathrm{X} \operatorname{lnR}$, under the control of strong copper responsive promoter $\mathrm{P}_{\mathrm{tcu} 1}(\mathrm{LV}$ et al., 2015). Such copper responsive promoters have also been shown to overexpress the genes in Cryptococcus neoformans (Lamb et al., 2013). Thus, this strategy opens horizons for hyper production of specific cellulases, under non inducing conditions, with higher purity and reduced downstream processing costs. In another study hyper production of pectinases from A. Niger, has been achieved by overexpression of transcription factor GaaR and deletion of creA (Alazi et al., 2017).

Furthermore, the role of sigma factors can also be explored to increase the rate of transcription in different fungi. Such engineering studies have been done in cyanobacteria to increase the bioproduction of valuable products like ethanol, fatty acids, hydrogen etc. (Srivastava et al., 2020).

\subsubsection{Increased expression by translation regulation}

Bioproduction of industrially relevant enzymes requires engineering at multiple gene expression levels. Translation processes can be explored in this direction. Translation processes are not only responsible for the synthesis of protein from mRNA, but also affect their folding, structure, and secretion of proteins. To achieve higher production of enzymes, all mRNAs must be translated into proteins and folded into correct structures. Quantitative proteomics studies have indicated the role of $\sim 17$ different translation related factors in increasing the production of xylanases in P. pastoris (Lin et al., 2013). Heterologous gene expression of enzyme phytase, in engineered microbes, like $P$. pastoris can be improved by overexpression of Bcy1, a regulatory subunit of protein kinase A (Liao et al., 2020). Certain transcription factors like Fhl1p have shown a role in rRNA processing and transcription of ribosomal proteins, thus regulating the rate and efficiency of translation processes. Higher expression of Fhl1p, has shown to increase the level of phytases and pectinases (Zheng et al., 2019). Ribosome Binding Sites (RBS) are other effective targets that must be considered to 
improve the translational efficiency. Several RBS libraries are available and can be screened to increase the flux of translation reactions (Jervis et al., 2019). Such studies have been reported in E. coli and cyanobacterium Synechocystis sp. (Thiel et al., 2018).

The effectiveness of enzyme production is also limited by their accumulation in inappropriate compartments or improper translocation. This can be overcome by engineering the signal peptides. The native signal peptides can be replaced with more efficient and proven signal peptides. Higher production of penicillin G acylases (PGAs), cloned into E. coli have successfully been done using this approach (Pan et al., 2018). Original signal peptides were replaced with more efficient pelB and MalE signal peptides, resulting in overexpression of PGAs. Gene expression levels can also be regulated by using different induction systems. For large scale production of enzymes, high density growth of microorganisms is desired. Then, this can be followed by induction of gene expression. The most common systems used for this purpose are lac and tet systems (Llanes \& McFall, 1969; Orth et al., 2000). The main disadvantage of these systems is their low-level expression, in non-inducing conditions. These systems can be replaced by more promising theophylline inducible riboswitches, for enzyme expressions (Kamiura et al., 2019).

\subsubsection{Increased expression by codon optimization}

Codon optimization is a technology used to redesign a gene to improve the protein expression level without altering the amino acids. However, a protein is comprised of only 20 different types of amino acids and there are 64 codons. Out of these, 61 codons code for 20 amino acids ( 2 amino acids coded by 1 codon, 9 with 2 codons, 1 with 3 codons, 5 with 4 codons, and 3 with 6 codons) and three codons do not specify any amino acid and function as a termination codon. Codon degeneracy provides several options to encode a protein e.g. a 375 amino acid protein can be encoded by $10^{207}$ various sequences (Şen et al., 2020). All the possible codon sequences are not equally observed in nature; however, organisms prefer a 
synonymous codon over the other (codon bias) which directly corelated with the expression level of a gene. For example, in Homo sapiens amino acid leucine mostly (39.5\%) coded by CUG codon, while the same codon is used only $11.1 \%$ times to code this amino acids in $S$. cerevisiae (Şen et al., 2020). Codon optimization is considered an important factor to affect the gene expression level in different hosts. Using frequent and more host specific codons instead of the rarely observed ones level of protein expression can be improved by $10^{5}$ folds (Gustafsson et al., 2004). Various sequence design software such as Codon optimizer, Gene Designer, and OPTIMIZER are in trends to optimize the frequency of individual codon occurrence. The main factors which affects the expression of recombinant proteins include a selection of the proper host, the sequence of open reading frame and upstream and downstream regulatory elements (Ghahremanifard et al., 2018).

Codon optimization in E. coli: E. coli is a widely used host for heterologous protein production due to its fast growth, easy to genetic modification, and requirement of inexpensive culture medium. Usage of codon biased methods improves the expression of heterologous proteins expression in E. coli. The competition for rare tRNA also affects enzyme expression level e.g. AGA and AGG codon which code for arginine are rare in $E$. coli and may cause translation errors or low expression. The codon bias can be mitigated by expressing the genes code for rare tRNA or using mutagenesis to change the rare codons with more commonly used codons (Liu et al., 2012a). Various codon optimizations examples are discussed in table 2.

Codon optimization in Pichia pastoris: P. pastoris is a widely utilized host for heterologous protein expression for research and industrial scale. However, the expression level of different proteins is affected by factors linked to mRNA translation, post translation modification, and secretion efficiency (Tian et al., 2012). Tian et al. cloned an acetyl xylan esterase (AXE1) cDNA from edible mushroom (Volvariella volvacea) into P. pastoris and 
reported lower expression level $1.88 \mathrm{IU} / \mathrm{ml}$ after 8 days, after codon optimization by reducing GC content from $55.49 \%$ to $48.62 \%$ they able to increase expression of AXE1 up to 136.45 $\mathrm{U} / \mathrm{ml}$ (Tian et al., 2012). T. reesei cellulase has many industrial applications including paper, and textile industry, Akcapiner et al. applied codon optimization for endoglucanase 1 (EGI) to express it in P. pastoris and able to increase its activity by 1.24 fold as compared to native EGI (Akcapinar et al., 2011) (more examples are discussed in Table 2).

\section{Engineering for improved and new catalytic activity}

Through the decade's biologists, and process engineers opted physical, structural, and genetic modification strategies to re-design the existing enzymes to provide high yields, selectivity, tolerance to high substrate concentrations with low enzyme loading. The advent of new recombinant tools and the availability of genome databases led to the development of efficient and economical processes resulting in enzymes performing natural and non-natural reactions. The strategies employed to improve the specific activity, stability, and selectivity of the enzymes are site directed mutagenesis, directed evolution, fusion of multiple enzymes using linkers, cell surface display technology, and introduction of uncanonical amino acids.

\subsection{Directed evolution}

The scenario of synthetic catalysts for reactions of commercial interest can be replaced with biocatalysts. These biological catalysts can perform highly enantio and regioselective reaction mechanisms on the substrates of interest with an enhanced specific reaction rate. But the commercial reaction processes and their physiological conditions do not favors the naturally occurring enzymes. Directed evolution is one such technique that complements novel or improved functionalities on the enzymes. Evolution is the Darwinian principle of natural selection, directed or laboratory evolution mimics the Darwinian theory, and forward engineer the enzymes to adapt and recombine to yield a recombinant enzyme with enhanced properties at a higher pace (Arnold, 2018). How does directed evolution work? The 
mechanism couple random mutagenesis, DNA recombination, selection, and high throughput screening strategies (fig. 1a). In the concept of directed evolution, a mutant library is created, then selected or screened based on the desirable trait, the process is repeated ' $n$ ' times until the desirable trait is observed. Higher mutants in the library can be observed if there is a probability of an increased number of mutations, the mutations can be induced in the peptide in the genomic level either by error prone PCR, site saturation, chemical mutagenesis, and DNA shuffling. Approximately 5.6 mutations can be observed per amino acid, then if the peptide is 20 amino acid long, the mutant library obtained have a very high chance of having the mutant with the desired phenotype. The mutant gene obtained will be cloned into a compatible plasmid and transformed into a chassis strain for functional expression of the recombinant protein. Then the important approach is the selection and screening of the large number of mutants generated by directed evolution. In a study whole cell biocatalyst Bacillus amyloliquefaciens SS35 was irradiated with UV light to generate the mutants that could produce endogluconase and carboxy methylcellulase (CMCase) enzyme with improved activity and stability. The CMCase from the mutants displayed $\mathrm{pH}$ stability in the alkaline range 7.0 - 11.0, with 1.6 - 4.1-fold increase in activity. The enzymatic hydrolysis of lignocellulosic biomass using the mutant enzyme resulted in 1.8-fold increase in sugar release (Singh et al., 2020b). Similarly, the rate limiting enzyme of cellulose hydrolysis, and the component of cellulase, the $\beta$-glucosidase, is sensitive to the end product glucose, although various glucose tolerant enzymes were discovered, a novel Bgl6 with inhibitory concentration $\mathrm{IC}_{50} \sim 3.5 \mathrm{M}$ glucose, with poor thermal stability at $50{ }^{\circ} \mathrm{C}$, has undergone random mutagenesis, the resultant M3 mutant showed 3 fold increase in catalytic activity $\left(\mathrm{K}_{\mathrm{cat}} / \mathrm{K}_{\mathrm{m}}\right)$. The cellobiose hydrolysis using the mutant M3 enzyme has $20 \%$ increased conversion efficiency than the wild type (Cao et al., 2015). Directed evolution generates new functional variants but the major challenge involved is a theoretically small fraction of the whole 
sequence is accessible for screening and selection. Hence generation of wide quality and quantity of mutant libraries is desired. Some of the enzymes that are evolved to perform new functions are P411 engineered from Cytochrome P450. The mutant P411 is able to perform intermolecular benzylic C-H amination with >99\% enantioselectivity. The Rhodothermus marinus cytochrome $\mathrm{C}$ oxidase evolved enzyme with chemoselective for $\mathrm{Si}-\mathrm{H}$ insertion, could catalyse chiral organosilicon product formation from ethyl-2-diazoproponate and phenyl dimethyl silane, and the same enzyme was observed to catalyse chiral organoborane product formation from carbene precursors and borylating agents (Arnold, 2018). An unspecific peroxygenases was observed as the missing link between heme and cytochrome P450 peroxidases, these new peroxidases are soluble extracellular and highly stable observed as in Cyclocybe aegerita. The gene responsible was expressed in S. cerevisiae and undergone directed evolution by inducing 4 mutations in the native signal peptide and 5 mutations in the mature protein, resulting in 27-fold increase in secretion and 18 -fold increase in $\mathrm{K}_{\mathrm{cat}} / \mathrm{K}_{\mathrm{m}}$ (Alcalde, 2015). Hence directed evolution can fine tune the enzymes to perform new reactivities. Few other examples of enzymes improved by directed evolution are tabulated (Table 3).

\subsection{Site directed mutagenesis}

Site directed mutagenesis (SDM) is a specific tool to perform rational or semi rational mutagenesis, which involves editing of an amino acid at a particular site that do alter the functionality of the protein (fig. 1b). SDM is possible in enzymes with known sequence, structure, active site conformation, evolutionary relations, and reaction mechanism (Baweja et al., 2016). Either by insertion or deletion at a specific site, in less time, the recombinant protein with increased specificity, stability, activity, and solubility can be obtained. The commercially available enzymes like proteases and lipases have improved effectively. For example, natokinase, a bacterial serine protease, having applications in developing 
cardiovascular drugs, catalytic efficiency, and stability was increased by 2 rounds of SDM. Similarly combined random mutagenesis and SDM of Harobin, a serine protease improved its fibrinolytic and antithrombosis effect (Baweja et al., 2016). A series of site directed mutagenesis in Bacillus pumilus W3 resulted in a mutant S208G/F227A, in which CotA laccase, the enzyme responsible for decolorization of dyes and degradation of toxic substances was observed to have mutations at Gly208 and Ala227 sites, that decreased the thermal stability but increased the catalytic efficiency by 5.1-fold (Xu et al., 2016). Hence the knowledge on the structure and the configuration is very much important before inducing SDM, the amino acid change in one or more sites may have a positive or negative influence on the resulting protein. In a L-arginine biosynthesis strain Corynebacterium crenatum, in a rate limiting enzyme N-acteyl-L-glutamate kinase, D311 and D312 amino acids are replaced by arginine, resulting in 3.7-fold and $14.6 \%$ increase in inhibitory concentration and enzyme activity respectively (Zhang et al., 2015). In a study carried out by Fang and associates ornithine carbamylase that catalyse the formation of ornithine and carbomoyl phosphate from citrulline and arginine was engineered through SDM, at 9 different sites, out of which H140A, Q143W mutants displayed 2-3 times increase in catalytic activity and increased tolerance to ethanol. Another mutant with a point mutation D236R has shown a 1.4-fold increase in thermal stability (Fang et al., 2020). Either single or multiple mutations in the mature protein with a sophisticated screening technique would be an ideal approach for generating desirable enzymes with improved functionalities.

\subsection{Fusion protein linkers}

Either in natural or non-natural biosynthesis reactions, the end-product may not be produced in a single step, so the complex coupled reactions have various limitations in the form of stability, productivity, insufficient functional expression, and tolerance to the intermediates. Even the traditional site directed and random mutagenesis with high throughput screening 
methods makes the selection of protein with desirable phenotype tedious. But the answer is? In nature, the complex biosynthesis pathways and other cascade reactions are finely regulated either by extracellular or intracellular open reading frames, subcellular reaction compartments, membrane associated complexes, protein clusters, and modular fusion proteins. If we can mimic the natures ability to bring the different enzymes in proximity, we can overcome the limitations in the commercial scale. A new technology of fusing the two or more catalytically complementary enzymes resulted in chimeric or recombinant protein with enhanced catalytic efficiency. For example, a 230 KDa cellulases from Anaerocellum thermophilum are the natural enzyme clusters with active endo and exogluconase activity. Later various dehydrogenases and transaminases are artificially fused using the linkers like fusion of alcohol dehydrogenase and cyclohexanone monooxygenase. The fused product could mediate two step reaction for the conversion of cyclohexanol (alcohol) into $\varepsilon^{-}$ caprolactone (ketone) (Aalbers \& Fraaije, 2017). With the fused enzyme cascade or multistep experiment, complex molecules can be produced in a single step without the need of separation and purification of the intermediates. It was also observed that covalently linked enzymes outperformed the mixture of enzymes in expression levels, conversion rates, stability, and activity (Aalbers \& Fraaije, 2017). So how these enzymes are fused? Multiple genes coding for these proteins are arranged in an open reading frame without stop codons in between each gene, wherein a sequence encoding peptide linker is introduced, further transcription, translation and posttranslational modifications yields a fused protein (fig. 1c). The activity and the stability of the fused protein depends on order of the genes and the linker of choice, for example Pazmiño and co-workers fused phosphite dehydrogenase (PTDH), NADPH cofactor recycling enzyme with Baeyer-Villiger monooxygenase (BVMO) enzyme, the fused enzyme has displayed complete catalytic conversion efficiency, in either of the orientations PTDH-BVMO or BVMO-PTDH. However in a redox neutral cascade reaction 
by coupled alcohol dehydrogenase (Tb $\mathrm{ADH})$ from Thermoanaerobacter brockii and cyclohexanone monooxygenase (Tm CHMO) from Thermocrispum municipale, $\mathrm{Tb} \mathrm{ADH}-$ Tm CHMO has almost retained wild type activity, and Tm CHMO - Tb ADH has four fold reduced ADH activity (Aalbers \& Fraaije, 2019). Similarly, the composition of the linker, physical characterisitics (flexibility, rigidity, hydrophilicity, hydrophobicity), length has an impact on the stability, activity, and turnover of the fused enzyme. In a study of effect of linker length, repetitive units of three amino acids proline, alanine, and serine of different length say PAS 60, PAS 40, and PAS 20 sequences are used to fuse alcohol dehydrogenase and transaminase, which converts alcohols to amines. Final observations were interesting to find, how important is the length of the linker; PAS 60 has the highest soluble expression levels, PAS 40 highest retaining of specific activity, and PAS 20 has 2-fold increased conversion efficiency than the individual enzymes. Various research groups have worked on the characterization of linkers, its efficiency, based on the simulations and structure mediated studies resulted in the construction of linker libraries. It was observed that glycine rich linkers are flexible, and alanine and lysine rich linkers are rigid in nature (Chen et al., 2017). These linkers are not just the connections between two proteins, it has a major role in posttranslational modifications, enzyme orientation, display of an active site for substrate binding and further reaction rate (Chen et al., 2017). These fusion proteins can display their activities in various fields like pharmaceuticals, food and beverages, bulk, and specialty chemicals. For example, astaxanthin, a well-known food grade additive, red-colourant, having anti-oxidant activity is produced by various plants and microorganisms. In a study two bacterial enzymes, $3,3^{\prime}$ - $\beta$-carotene hydroxylase (CRTZ) and 4,4'- $\beta$-carotene oxygenase (CRTW) are fused with different linker combinations, the fused protein can convert $\beta$-carotene to astaxanthin. After the expression in E. coli the fused protein with glycine rich small (10 a.a) and medium (20 a.a) size linkers has higher activity than the longer (29 a.a) linker, as shorter linkers might 
have enhanced the substrate and intermediate channelling between the proteins (Nogueira et al., 2019). These hybrid or fused proteins gaining new functionality, derived from individual enzymes or domains, can either misfold, or lead to impaired activity after the posttranslational modifications without the presence of linkers. Linker with composition $($ GGGGS)n $(n<6)$; enhance flexibility and solubility, similarly $($ EAAAK $) n(n<6)$ imparts rigidity and helical linker between the proteins (Chen et al., 2017). Usually flexible linkers are more preferred, but in a study related to monooxygenase activity of cytochrome P450s, $B$. subtilis flavodoxin was fused with $E$. coli flavodoxin reductase using flexible (GGGGS)n linker and rigid (E/LPPPP)n linker, due to greater separation the fused protein with rigid linker outperformed (Bakkes et al., 2017). Similarly, in a leucine biotransformation, where cofactor regeneration is necessary, formate dehydrogenase and leucine dehydrogenase enzymes are fused using a rigid linker, that tends to form a tunnel like structure favouring the intramolecular movement between C-terminal FDH and N-terminal LeuDH. The combination FDH-3 rigid linkers (R3)-LDH increased relative specific activities up to 145 and $103 \%$ respectively (Zhang et al., 2017). We observed that linker could enhance the activity, but linkers have a functional role in solubility and stability of the protein, the work carried out by Degregorio and associates explains the increased solubility of human liver cytochrome P450s by fusing with reductase from Bacillus megaterium BM3 using 3 and 5 glycine residues as linkers. Both the fused proteins displayed stability, increased solubility, fused protein with 3 glycine linker has highest redox potential and NADPH oxidation state, whereas in 5 glycine linker fusion protein Vmax increased 2-fold (Degregorio et al., 2017). Basic pre-requisites to be considered in designing fusion proteins are; (i) efficient translation machinery, (ii) orderly fashion of proteins to be fused based on structure, size and confirmation, and (iii) designing of linkers for proper flexibility to retain functionality and catalytic efficiency (Elleuche, 2015). Usually longer the linker, the peptide will be prone to proteolytic cleavage thereby 
separating the fused proteins, hence optimum length of linker to be accessed either through literature search or by computational simulations.

\subsection{Unnatural amino acids}

The proteins and peptides are synthesized using canonical amino acids, that do regulate biological complex reactions, and recruit co-factors or undergo post-translational modifications for additional bioconversions (Drienovská \& Roelfes, 2020). For example, covalent binding of cyclins to kinases, chaperons to HSP90, NAD to sirtuins, and AMP to AMP activated kinase results in an increase in catalytic efficiency $\left(\mathrm{K}_{\mathrm{cat}} / \mathrm{K}_{\mathrm{m}}\right)($ Darby et al., 2017). In the usual mRNA translational process L-amino acids (aa) are incorporated for the peptide chain biosynthesis, but few D-amino acids are found which are the derivatives obtained through enzymatic conversion of L-aa. The non-ribosomal, ribosomal, and post translational modified peptides have a racemic mixture of $\mathrm{D}$ and $\mathrm{L}$ aa's, and further, undergo conformational resolution by a few downstream enzymes. For example, in dehydratases and hydrogenases L-serine / L-threonine are converted to D- alanine / D-ethyl glycine (Vagstad et al., 2019). The concept of a designer or recombinant enzymes has brought great attention due to their capability to catalyse abiological transformations or the reactions which are not existed in nature, improve the catalytic nature, substrate binding capacity, or the specific activity in the existing biocatalysts. How do these unnatural or non-canonical amino acids have a role in the engineering the enzymes? Incorporation of these non-canonical amino acids during translation yields a peptide with unique reactive functional groups as the side chains, because of which the catalytic repertoire of the individual enzyme could be expanded (Hu \& Wang, 2016). These changes could also impart novel functionalities and improve the specific activity of the enzymes. So how to alter the genetic code for the incorporation of unnatural amino acids. Sung Lee and co-workers have explained in detail the two ways of incorporation, (i) site specific incorporation, wherein a stop codon or 4 base codon is 
assigned for unnatural amino acids following orthogonal translation system, or Re-assigning or replacement of one natural amino acid residue with unnatural amino acids. For example, genetic code UUU re-assigned to L-3-(2-napthyl) alanine (LNA), but in translation AU base pairing dominates GU pairing hence instead of LNA higher concentrations of natural phenylalanine got incorporated into the peptide chain. As the genetic code is degenerate, if a rare codon is re-assigned like AGG, decoded by less abundant tRNA's and 1 out of 6 codons for arginine, the resulting peptide chain is incorporated with abundant unnatural amino acids (Lee et al., 2015). The active site confirmation and the surface residues are very much important in maintaining the substrate specificity, and reactivity of the enzyme. Incorporation of these unnatural amino acids could assist in fine tuning of the active site, but the approach is not just confined to the active site, in 2001, 4 phenylalanine residues in Pvu II restriction enzyme were replaced with ortho (o), meta (m), and para (p) - fluorophenylalanine, the enzyme incorporated with $\mathrm{m}$-fluorophenylalanine has 2-fold improvement in its specific activity than the wild type (Dominguez Jr. et al., 2001). Similarly, replacement of tyrosine with m-flurotyrosine in transaminase, increased the enzyme stability and final titers of phenyl ethylamine, replacement of methionine with norleucine in cytochrome P450 peroxidase increased its activity by 2-fold (Drienovská et al., 2018).

The major requisites for cell free protein or peptide synthesis are co-factors, salts, amino acid residues (standard and unnatural), tRNA's, mRNA template, and energy source. The translation can be carried out either via frameshift suppression, global suppression, amber suppression, or sense codon re-assignment as discussed above to incorporate unnatural amino acids (Gao et al., 2019). Introduction of these unnatural amino acids in the cellular protein machinery would improve the chemical and thermal stability, enable access to metal ligands, co-factors, resulting in hybrid enzymes catalysing physiologically irrelevant but commercially important reactions. 


\subsection{Surface display technology}

The concept is comparable to the immobilization technique wherein enzymes are either adsorbed on to an inert matrix, covalently linked with a support, entrapped in a medium through ionic interactions or hydrogen bonding. The immobilization technique has offered the biocatalysts the means to increase its stability, resistance to harsh process conditions, and more importantly the ability to reuse the catalyst. In a whole cell or enzyme mediated biosynthesis, the major drawbacks usually observed are substrate transport and enzyme purification. The surface display technology (SDT) addresses these limitations by presenting the proteins or peptides on the extracellular surface of the cell, where the reaction could occur in the external medium preventing the substrate transport inside the cell (Madhavan et al., 2017). So how does the protein or peptide gets displayed? The protein to be displayed (Traveller protein) is fused with the native or heterologous anchor (Carrier) protein. Later the signal peptide in the carrier assists the traveler in transfer from inner membrane, periplasm and finally anchored on the outer membrane. The orientation of the traveler protein, and size is dependent on the carrier protein. The SDT can be applied in a different range of host cells from viral capsids, bacterial spores, other prokaryotes, and eukaryotes (Smith et al., 2015). The presenting of proteins or peptides on the cell surface assist in protein library screening, recombinant viral vaccines, biosensors, whole cell biocatalysts in bioremediation, bioconversion, biotransformation, and biodegradation processes (Gallus et al., 2020). The successful display of the passenger protein involves a series of networks in the host cells, beginning with an efficient signal peptide to direct the traveler towards the secretory pathway, recombining with the anchor or surface motifs, and further tagging of epitope for expression and detection. The most widely used prokaryotic surface motifs are a fused protein outer membrane protein A (OmpA)-lipoprotein (LPP), an autotransporter and Ice nucleation protein (INP), these transporters differ in their efficiency like OmpA-LPP is 
common carrier protein, but INP is a new carrier protein with higher display efficiency and have a linker to display at a farther distance. The display of proteins or peptides on phages or prokaryotes have few limitations like simple post translational modifications and size of the traveler protein, and as bacteria have low tolerance to organic solvents, enzymes that regulate complex reactions in the presence of organic solvents cannot be expressed. Although yeast has a lower growth rate and transformational efficiencies, the ability to tolerate harsh conditions, available genetic tools, and efficient post translational modifications make the yeast as the suitable host for the homologous or heterologous cell surface protein display (fig. 1d). In a study wherein cell surface, heterologous expression of xylose reductase and $\beta$-Dglucosidase on the $S$. cerevisiae cells resulted in simultaneous co-fermentation of cellobiose and xylose to xylitol with 2.5-fold increase in the yields (Guirimand et al., 2019b). Similarly, expression of glucoamylase and glucose oxidase using a - agglutinin as the anchoring motif resulted in 4-fold increase in the reaction rate in comparison to the individual rates (Fan et al., 2020). Even in the case of biodegradation experiments wherein the whole cells tolerance to those unfriendly substrates makes the degradation process uneconomical, here a novel enzyme PETase that could degrade polyethylene terephthalate (PET) was displayed on Pichia pastoris (Komagataella phaffii) resulted in increased thermal and $\mathrm{pH}$ stability, and 36-fold increase in enzyme turnover rate and stable reactive specific activity after 7 repetitions (Chen \& Arnold, 2020). In a prokaryotic system INP from Pseudomonas syringae as the anchor protein, carboxylesterase encoding gene (Car EW) from Bacillus sp. K91, and a gfp protein was expressed in E. coli BL21 (DE3) cells using pET-28a (+) vector. At optimal temperature of $45^{\circ} \mathrm{C}$ and $\mathrm{pH}-9.0,1.5 \mathrm{mg} / \mathrm{ml}$ of diisobutyl phthalate was degraded by $10 \mathrm{U}$ of carboxylesterase displayed on the cell surface (Ding et al., 2020). In comparison to the conventional whole cell biocatalysis, where intracellular enzymes are used in biosynthesis or 
biodegradation processes, the cell surface display could reduce the mass transfer limitations by preventing the transport of substrates or products to or from the cell.

\section{Challenges and future perspectives}

Microbes are ubiquitous in nature and considered as the most prominent source for biochemicals and functional enzymes (Thapa et al., 2019). The enzyme industry is the dominant industry in the world and there is always a demand for new enzymes having improved activity, stability, and substrate specificity. Despite advances in biotechnology still, more than $99 \%$ of microbial flora is unexplored. The interaction between physical and chemical factors of the environment modulate the microbiological universe thus it's important to study these factors to predicts the micro inhabitants and vice versa. The recent advances in metagenomics, genome mining, and high throughput sequencing technologies are generating a huge amount of data that is not proportional to its biological significance (Alves et al., 2018). With the advanced bioinformatic tools, metagenomics data analysis could be able to transform raw data into useful biological information. Other challenge is to integrate the outcomes of the data analysis with already existing knowledge. Along with these challenges the success of novel enzyme research depends on factors such as gene size and its abundance in metagenomic sample, availability of host vector system, efficiency of screening systems. There is a need to find new hosts, broad host range vectors and develop biosensors to speed up screening methods for identification of positive clones in thousands of metagenomic library.

Further research is required to explore the novel techniques of enzyme production to full fill the increasing consumers demand at an industrial and commercial scale. With the advancements of molecular biology tools (promoter engineering, translation and transcriptional factors regulation, codon optimization, etc.) researchers able to increase enzyme production many folds. Use of synthetic gene may help to overcome the barriers of 
codon biasing, allow the introduction of site-specific mutation and expression under choicest promoters, enhancer, and terminators for high level production. To make the enzyme-based processes more efficient enzymes should have higher activity, stability, and selectivity. Regardless of recent advances in enzyme engineering techniques (site directed mutagenesis, surface display technology, fusion proteins, use of unusual amino acids, etc.) it is a complicated task to mutate the enzymes for desired properties. Understanding structure modeling, computational enzyme engineering, and associated fields will be helpful in engineering designer enzymes have high activity, stability, and specificity properties required for industrial applications.

\section{Conclusions}

Green chemistry is getting attention around the world as enzymes-based reactions are more advantageous due to the formation of fewer side products. There are many successful examples of novel enzyme discovery and improvement using advanced molecular biotechnology approaches like metagenomics, site directed mutagenesis. However, applications are limited with lab scale research and further strategies are needed to integrate in industrial scale to strengthen the enzyme-based industry. In the future, the association of experimental and advanced computational tools of enzyme engineering will lead to the discovery of novel designer enzymes having multifunctional activities and desired industrial applications.

\section{Acknowledgments}

The authors would like to acknowledge the KU Research Professor Program of Konkuk University, Seoul, South Korea. 


\section{References}

Aalbers, F.S., Fraaije, M.W. 2017. Coupled reactions by coupled enzymes: alcohol to lactone cascade with alcohol dehydrogenase-cyclohexanone monooxygenase fusions. Applied microbiology and biotechnology, 101(20), 7557-7565.

Aalbers, F.S., Fraaije, M.W. 2019. Enzyme Fusions in Biocatalysis: Coupling Reactions by Pairing Enzymes. ChemBioChem, 20(1), 20-28.

Akbulut, N., Tuzlakoğlu Öztürk, M., Pijning, T., İşsever Öztürk, S., Gümüşel, F. 2013. Improved activity and thermostability of Bacillus pumilus lipase by directed evolution. Journal of biotechnology, 164(1), 123-129.

Akcapinar, G.B., Gul, O., Sezerman, U. 2011. Effect of codon optimization on the expression of Trichoderma reesei endoglucanase 1 in Pichia pastoris. Biotechnology progress, 27(5), 1257-1263.

Al-Ghanayem, A.A., Joseph, B. 2020. Current prospective in using cold-active enzymes as eco-friendly detergent additive. Applied microbiology and biotechnology, 104, 28712882.

Alazi, E., Knetsch, T., Di Falco, M., Reid, I.D., Arentshorst, M., Visser, J., Tsang, A., Ram, A.F.J. 2018. Inducer-independent production of pectinases in Aspergillus niger by overexpression of the D-galacturonic acid-responsive transcription factor gaaR. Applied Microbiology and Biotechnology, 102(6), 2723-2736.

Alazi, E., Knetsch, T., Di Falco, M., Reid, I.D., Arentshorst, M., Visser, J., Tsang, A., Ram, A.F.J. 2017. Inducer-independent production of pectinases in Aspergillus niger by overexpression of the D-galacturonic acid-responsive transcription factor gaaR. Applied Microbiology and Biotechnology, 102(6), 2723-2736.

Alcalde, M. 2015. Engineering the ligninolytic enzyme consortium. Trends in Biotechnology, 33(3), 155-162. 
Almeida, J.M., Alnoch, R.C., Souza, E.M., Mitchell, D.A., Krieger, N. 2019. Metagenomics: Is it a powerful tool to obtain lipases for application in biocatalysis? Biochimica et Biophysica Acta (BBA) - Proteins and Proteomics, 1868(2), 140320.

Alves, L.d.F., Westmann, C.A., Lovate, G.L., de Siqueira, G.M.V., Borelli, T.C., Guazzaroni, M.-E. 2018. Metagenomic approaches for understanding new concepts in microbial science. International journal of genomics, 2018.

Amobonye, A., Singh, S., Pillai, S. 2019. Recent advances in microbial glutaminase production and applications-a concise review. Critical reviews in biotechnology, 39(7), 944-963.

Araújo, R., Casal, M., Cavaco-Paulo, A. 2008. Application of enzymes for textile fibres processing. Biocatalysis and Biotransformation, 26(5), 332-349.

Arnold, F.H. 2018. Directed Evolution: Bringing New Chemistry to Life. Angewandte Chemie International Edition, 57(16), 4143-4148.

Bakkes, P.J., Riehm, J.L., Sagadin, T., Rühlmann, A., Schubert, P., Biemann, S., Girhard, M., Hutter, M.C., Bernhardt, R., Urlacher, V.B. 2017. Engineering of versatile redox partner fusions that support monooxygenase activity of functionally diverse cytochrome P450s. Scientific reports, 7(1), 9570.

Baweja, M., Nain, L., Kawarabayasi, Y., Shukla, P. 2016. Current Technological Improvements in Enzymes toward Their Biotechnological Applications. Frontiers in Microbiology, 7(965).

Bersaneti, G.T., Pan, N.C., Baldo, C., Celligoi, M. 2018. Co-production of Fructooligosaccharides and Levan by Levansucrase from Bacillus subtilis natto with Potential Application in the Food Industry. Appl Biochem Biotechnol, 184(3), 838-851.

Bhatia, R.K., Ullah, S., Hoque, M.Z., Ahmad, I., Yang, Y.-H., Bhatt, A.K., Bhatia, S.K. 2020a. Psychrophiles: A source of cold-adapted enzymes for energy efficient biotechnological industrial processes. Journal of Environmental Chemical Engineering, 104607. 
Bhatia, S.K., Bhatia, R.K., Jeon, J.-M., Kumar, G., Yang, Y.-H. 2019. Carbon dioxide capture and bioenergy production using biological system-A review. Renewable and Sustainable Energy Reviews, 110, 143-158.

Bhatia, S.K., Bhatia, R.K., Yang, Y.-H. 2017. An overview of microdiesel - A sustainable future source of renewable energy. Renewable and Sustainable Energy Reviews, 79, 1078-1090.

Bhatia, S.K., Jagtap, S.S., Bedekar, A.A., Bhatia, R.K., Patel, A.K., Pant, D., Rajesh Banu, J., Rao, C.V., Kim, Y.-G., Yang, Y.-H. 2020b. Recent developments in pretreatment technologies on lignocellulosic biomass: Effect of key parameters, technological improvements, and challenges. Bioresource Technology, 300, 122724.

Bhatia, S.K., Mehta, P.K., Bhatia, R.K., Bhalla, T.C. 2014. Optimization of arylacetonitrilase production from Alcaligenes sp. MTCC 10675 and its application in mandelic acid synthesis. Applied microbiology and biotechnology, 98(1), 83-94.

Bollinger, A., Molitor, R., Thies, S., Koch, R., Coscolín, C., Ferrer, M., Jaeger, K.-E. 2020. Organic-Solvent-Tolerant Carboxylic Ester Hydrolases for Organic Synthesis. Applied and Environmental Microbiology, 86(9), e00106-20.

Brumano, L.P., da Silva, F.V.S., Costa-Silva, T.A., Apolinário, A.C., Santos, J.H.P.M., Kleingesinds, E.K., Monteiro, G., Rangel-Yagui, C.d.O., Benyahia, B., Junior, A.P. 2019. Development of L-Asparaginase Biobetters: Current Research Status and Review of the Desirable Quality Profiles. Frontiers in Bioengineering and Biotechnology, 6(212).

Cai, Y., Xia, M., Dong, H., Qian, Y., Zhang, T., Zhu, B., Wu, J., Zhang, D. 2018. Engineering a vitamin B12 high-throughput screening system by riboswitch sensor in Sinorhizobium meliloti. BMC Biotechnology, 18(1), 27. 
Cao, L.-c., Wang, Z.-j., Ren, G.-h., Kong, W., Li, L., Xie, W., Liu, Y.-h. 2015. Engineering a novel glucose-tolerant $\beta$-glucosidase as supplementation to enhance the hydrolysis of sugarcane bagasse at high glucose concentration. Biotechnology for biofuels, 8(1), 202.

Chandra, P., Enespa, Singh, R., Arora, P.K. 2020. Microbial lipases and their industrial applications: a comprehensive review. Microbial Cell Factories, 19(1), 169.

Chen, H., McGowan, E.M., Ren, N., Lal, S., Nassif, N., Shad-Kaneez, F., Qu, X., Lin, Y. 2018. Nattokinase: A Promising Alternative in Prevention and Treatment of Cardiovascular Diseases. Biomarker insights, 13, 1177271918785130-1177271918785130.

Chen, H., Wu, B., Zhang, T., Jia, J., Lu, J., Chen, Z., Ni, Z., Tan, T. 2017. Effect of Linker Length and Flexibility on the Clostridium thermocellum Esterase Displayed on Bacillus subtilis Spores. Applied Biochemistry and Biotechnology, 182(1), 168-180.

Chen, K., Arnold, F.H. 2020. Engineering new catalytic activities in enzymes. Nature Catalysis, 3(3), 203-213.

Choi, J.-M., Han, S.-S., Kim, H.-S. 2015. Industrial applications of enzyme biocatalysis: Current status and future aspects. Biotechnology advances, 33(7), 1443-1454.

Chua, G., Morris, Q.D., Sopko, R., Robinson, M.D., Ryan, O., Chan, E.T., Frey, B.J., Andrews, B.J., Boone, C., Hughes, T.R. 2006. Identifying transcription factor functions and targets by phenotypic activation. Proceedings of the National Academy of Sciences of the United States of America, 103(32), 12045-12050.

Contesini, F., Junior, J., Macedo, G., Sato, H., Carvalho, P. 2012. Lipases in the Pharmaceutical Industry: An Approach for Racemic Drugs.

Darby, J.F., Atobe, M., Firth, J.D., Bond, P., Davies, G.J., O'Brien, P., Hubbard, R.E. 2017. Increase of enzyme activity through specific covalent modification with fragments. Chemical Science, 8(11), 7772-7779. 
De Waele, S., Vandenberghe, I., Laukens, B., Planckaert, S., Verweire, S., Van Bogaert, I.N.A., Soetaert, W., Devreese, B., Ciesielska, K. 2018. Optimized expression of the Starmerella bombicola lactone esterase in Pichia pastoris through temperature adaptation, codon-optimization and co-expression with HAC1. Protein Expr Purif, 143, $62-70$.

Degregorio, D., D'Avino, S., Castrignanò, S., Di Nardo, G., Sadeghi, S.J., Catucci, G., Gilardi, G. 2017. Human Cytochrome P450 3A4 as a Biocatalyst: Effects of the Engineered Linker in Modulation of Coupling Efficiency in 3A4-BMR Chimeras. Frontiers in Pharmacology, 8(121).

Ding, J., Zhou, Y., Wang, C., Peng, Z., Mu, Y., Tang, X., Huang, Z. 2020. Development of a whole-cell biocatalyst for diisobutyl phthalate degradation by functional display of a carboxylesterase on the surface of Escherichia coli. Microbial Cell Factories, 19(1), 114.

Dominguez Jr., M.A., Thornton, K.C., Melendez, M.G., Dupureur, C.M. 2001. Differential effects of isomeric incorporation of fluorophenylalanines into PvuII endonuclease. Proteins: Structure, Function, and Bioinformatics, 45(1), 55-61.

Drienovská, I., Mayer, C., Dulson, C., Roelfes, G. 2018. A designer enzyme for hydrazone and oxime formation featuring an unnatural catalytic aniline residue. Nature Chemistry, 10(9), 946-952.

Drienovská, I., Roelfes, G. 2020. Expanding the enzyme universe with genetically encoded unnatural amino acids. Nature Catalysis, 3(3), 193-202.

Duarte, L., Matte, C.R., Bizarro, C.V., Ayub, M.A.Z. 2020. Review transglutaminases: part II-industrial applications in food, biotechnology, textiles and leather products. World Journal of Microbiology and Biotechnology, 36(1), 1-20. 
Dubey, M.K., Zehra, A., Aamir, M., Meena, M., Ahirwal, L., Singh, S., Shukla, S., Upadhyay, R.S., Bueno-Mari, R., Bajpai, V.K. 2017. Improvement Strategies, Cost Effective Production, and Potential Applications of Fungal Glucose Oxidase (GOD): Current Updates. Frontiers in Microbiology, 8(1032).

Eberhardt, F., Aguirre, A., Menzella, H.G., Peiru, S. 2017. Strain engineering and process optimization for enhancing the production of a thermostable steryl glucosidase in Escherichia coli. Journal of industrial microbiology \& biotechnology, 44(1), 141-147.

Elleuche, S. 2015. Bringing functions together with fusion enzymes-from nature's inventions to biotechnological applications. Applied microbiology and biotechnology, 99(4), $1545-1556$.

Ellilã, S., Bromann, P., NyyssÃnen, M., ItÃvaara, M., Koivula, A., Paulin, L., Kruus, K. 2019. Cloning of novel bacterial xylanases from lignocellulose-enriched compost metagenomic libraries. AMB Express, 9(1), 124.

Emond, S., Petek, M., Kay, E.J., Heames, B., Devenish, S.R.A., Tokuriki, N., Hollfelder, F. 2020. Accessing unexplored regions of sequence space in directed enzyme evolution via insertion/deletion mutagenesis. Nature Communications, 11(1), 3469.

Fan, S., Liang, B., Xiao, X., Bai, L., Xiangjiang, T., Lojou, E., Cosnier, S., Liu, A. 2020. Controllable Display of Sequential Enzymes on Yeast Surface with Enhanced Biocatalytic Activity toward Efficient Enzymatic Biofuel Cells. Journal of the American Chemical Society, 142.

Fang, H., Xia, L. 2013. High activity cellulase production by recombinant Trichoderma reesei ZU-02 with the enhanced cellobiohydrolase production. Bioresource Technology, 144, 693-697. 
Fang, R., Chandra Syahputra, J., Airhunmwunde, O., Wu, Y., Lv, C., Huang, J., Xiao, G., Chen, Q. 2020. Improving the enzyme property of ornithine transcarbamylase from Lactobacillus brevis through site-directed mutation. LWT, 133, 109953.

Far, B.E., Ahmadi, Y., Khosroshahi, A.Y., Dilmaghani, A. 2020. Microbial alpha-amylase production: progress, challenges and perspectives. Advanced Pharmaceutical Bulletin, 10(3), 350 .

Favaro, L., Jooste, T., Basaglia, M., Rose, S.H., Saayman, M., Görgens, J.F., Casella, S., van Zyl, W.H. 2012. Codon-optimized glucoamylase sGAI of Aspergillus awamori improves starch utilization in an industrial yeast. Applied microbiology and biotechnology, 95(4), 957-968.

Ferrandi, E.E., Previdi, A., Bassanini, I., Riva, S., Peng, X., Monti, D. 2017. Novel thermostable amine transferases from hot spring metagenomes. Applied Microbiology and Biotechnology, 101(12), 4963-4979.

Gallus, S., Peschke, T., Paulsen, M., Burgahn, T., Niemeyer, C.M., Rabe, K.S. 2020. Surface Display of Complex Enzymes by in Situ SpyCatcher-SpyTag Interaction. ChemBioChem, 21(15), 2126-2131.

Gao, W., Cho, E., Liu, Y., Lu, Y. 2019. Advances and Challenges in Cell-Free Incorporation of Unnatural Amino Acids Into Proteins. Frontiers in Pharmacology, 10(611).

Ghahremanifard, P., Rezaeinezhad, N., Rigi, G., Ramezani, F., Ahmadian, G. 2018. Designing a novel signal sequence for efficient secretion of Candida antarctica lipase B in E. coli: The molecular dynamic simulation, codon optimization and statistical analysis approach. International journal of biological macromolecules, 119, 291-305.

Goedegebuur, F., Dankmeyer, L., Gualfetti, P., Karkehabadi, S., Hansson, H., Jana, S., Huynh, V., Kelemen, B., Kruithof, P., Larenas, E., Teunissen, P., Ståhlberg, J., Payne, C., Mitchinson, C., Sandgren, M. 2017. Improving the thermal stability of 
cellobiohydrolase Cel7A from Hypocrea jecorina by directed evolution. Journal of Biological Chemistry, 292, jbc.M117.803270.

Gomes, C., Silva, A.C., Marques, A.C., Sousa Lobo, J., Amaral, M.H. 2020. Biotechnology Applied to Cosmetics and Aesthetic Medicines. Cosmetics, 7(2), 33.

Guerrand, D. 2017. Lipases industrial applications: focus on food and agroindustries. $O C L$ Oilseeds and fats crops and lipids, 24(4), D403.

Guerrero, E.B., de Villegas, R.M.D., Soria, M.A., Santangelo, M.P., Campos, E., Talia, P.M. 2020. Characterization of two GH5 endoglucanases from termite microbiome using synthetic metagenomics. Applied microbiology and biotechnology, 104(19), 83518366.

Guirimand, G.G., Bamba, T., Matsuda, M., Inokuma, K., Morita, K., Kitada, Y., Kobayashi, Y., Yukawa, T., Sasaki, K., Ogino, C. 2019a. Combined Cell Surface Display of $\beta$-dGlucosidase (BGL), Maltose Transporter (MAL11), and Overexpression of Cytosolic Xylose Reductase (XR) in Saccharomyces cerevisiae Enhance Cellobiose/Xylose Coutilization for Xylitol Bioproduction from Lignocellulosic Biomass. Biotechnology Journal, 14(9), 1800704.

Guirimand, G.G.Y., Bamba, T., Matsuda, M., Inokuma, K., Morita, K., Kitada, Y., Kobayashi, Y., Yukawa, T., Sasaki, K., Ogino, C., Hasunuma, T., Kondo, A. 2019b. Combined Cell Surface Display of $\beta$-d-Glucosidase (BGL), Maltose Transporter (MAL11), and Overexpression of Cytosolic Xylose Reductase (XR) in Saccharomyces cerevisiae Enhance Cellobiose/Xylose Coutilization for Xylitol Bioproduction from Lignocellulosic Biomass. Biotechnology Journal, 14(9), 1800704.

Gustafsson, C., Govindarajan, S., Minshull, J. 2004. Codon bias and heterologous protein expression. Trends in Biotechnology, 22(7), 346-353. 
Hammer, S.C., Knight, A.M., Arnold, F.H. 2017. Design and evolution of enzymes for nonnatural chemistry. Current Opinion in Green and Sustainable Chemistry, 7, 23-30.

Han, Y.-H., Choi, T.-R., Park, Y.-L., Park, J.Y., Song, H.-S., Kim, H.J., Lee, S.M., Park, S.L., Lee, H.S., Bhatia, S.K., Gurav, R., Yang, Y.-H. 2020. Enhancement of pipecolic acid production by the expression of multiple lysine cyclodeaminase in the Escherichia coli whole-cell system. Enzyme and microbial technology, 140, 109643.

Hazeena, S.H., Nair Salini, C., Sindhu, R., Pandey, A., Binod, P. 2019. Simultaneous saccharification and fermentation of oil palm front for the production of 2,3-butanediol. Bioresource Technology, 278, 145-149.

Hirose, Y. 2017. Chapter 17 - The Application of Oxidizing Enzymes for Hair Dyeing Products. in: Future Directions in Biocatalysis (Second Edition), (Ed.) T. Matsuda, Elsevier. Amsterdam, pp. 359-371.

Hu, C., Wang, J. 2016. Method for Enzyme Design with Genetically Encoded Unnatural Amino Acids, Vol. 580.

Huang, C., Zhao, C., Li, H., Xiong, L., Chen, X., Luo, M., Chen, X. 2018. Comparison of different pretreatments on the synergistic effect of cellulase and xylanase during the enzymatic hydrolysis of sugarcane bagasse. RSC Advances, 8(54), 30725-30731.

Jemli, S., Ayadi-Zouari, D., Hlima, H.B., Bejar, S. 2016. Biocatalysts: application and engineering for industrial purposes. Critical Reviews in Biotechnology, 36(2), 246-258.

Jervis, A.J., Carbonell, P., Vinaixa, M., Dunstan, M.S., Hollywood, K.A., Robinson, C.J., Rattray, N.J.W., Yan, C., Swainston, N., Currin, A., Sung, R., Toogood, H., Taylor, S., Faulon, J.-L., Breitling, R., Takano, E., Scrutton, N.S. 2019. Machine Learning of Designed Translational Control Allows Predictive Pathway Optimization in Escherichia coli. ACS Synthetic Biology, 8(1), 127-136. 
Jiang, Y., Duarte, A.V., van den Brink, J., Wiebenga, A., Zou, G., Wang, C., de Vries, R.P., Zhou, Z., Benoit, I. 2016. Enhancing saccharification of wheat straw by mixing enzymes from genetically-modified Trichoderma reesei and Aspergillus niger. Biotechnology letters, 38(1), 65-70.

Jiang, Y., Li, Z., Wang, C., Zhou, Y.J., Xu, H., Li, S. 2019. Biochemical characterization of three new $\alpha$-olefin-producing P450 fatty acid decarboxylases with a halophilic property. Biotechnology for biofuels, 12(1), 79.

Jones, A., Lamsa, M., Frandsen, T.P., Spendler, T., Harris, P., Sloma, A., Xu, F., Nielsen, J.B., Cherry, J.R. 2008. Directed evolution of a maltogenic $\alpha$-amylase from Bacillus sp. TS25. Journal of biotechnology, 134(3), 325-333.

Kamiura, R., Toya, Y., Matsuda, F., Shimizu, H. 2019. Theophylline-inducible riboswitch accurately regulates protein expression at low level in Escherichia coli. Biotechnology letters, 41(6), 743-751.

Kanelli, M., Vasilakos, S., Nikolaivits, E., Ladas, S., Christakopoulos, P., Topakas, E. 2015. Surface modification of poly(ethylene terephthalate) (PET) fibers by a cutinase from Fusarium oxysporum. Process Biochemistry, 50.

Karaoğlan, M., Erden-Karaoğlan, F. 2020. Effect of codon optimization and promoter choice on recombinant endo-polygalacturonase production in Pichia pastoris. Enzyme and microbial technology, 139, 109589.

Kelly, S.A., Magill, D.J., Megaw, J., Skvortsov, T., Allers, T., McGrath, J.W., Allen, C.C.R., Moody, T.S., Gilmore, B.F. 2019. Characterisation of a solvent-tolerant haloarchaeal (R)-selective transaminase isolated from a Triassic period salt mine. Applied Microbiology and Biotechnology, 103(14), 5727-5737.

Koszelewski, D., Pressnitz, D., Clay, D., Kroutil, W. 2009. Deracemization of Mexiletine Biocatalyzed by Ï\%o-Transaminases. Organic Letters, 11(21), 4810-4812. 
Koutsandreas, T., Ladoukakis, E., Pilalis, E., Zarafeta, D., Kolisis, F.N., Skretas, G., Chatziioannou, A.A. 2019. ANASTASIA: An Automated Metagenomic Analysis Pipeline for Novel Enzyme Discovery Exploiting Next Generation Sequencing Data. Frontiers in Genetics, 10(469).

Kroukamp, H., den Haan, R., van Wyk, N.1., van Zyl, W.H. 2013. Overexpression of native PSE1 and SOD1 in Saccharomyces cerevisiae improved heterologous cellulase secretion. Applied Energy, 102, 150-156.

Kumar Awasthi, M., Ravindran, B., Sarsaiya, S., Chen, H., Wainaina, S., Singh, E., Liu, T., Kumar, S., Pandey, A., Singh, L., Zhang, Z. 2020. Metagenomics for taxonomy profiling: tools and approaches. Bioengineered, 11(1), 356-374.

Kumari, U., Singh, R., Ray, T., Rana, S., Saha, P., Malhotra, K., Daniell, H. 2019. Validation of leaf enzymes in the detergent and textile industries: launching of a new platform technology. Plant biotechnology journal, 17(6), 1167-1182.

Lamb, T.M., Vickery, J., Bell-Pedersen, D. 2013. Regulation of gene expression in Neurospora crassa with a copper responsive promoter. G3 (Bethesda, Md.), 3(12), 2273-2280.

Lan, Y., Zhang, X., Liu, Z., Zhou, L., Shen, R., Zhong, X., Cui, W., Zhou, Z. 2017. Overexpression and characterization of two types of nitrile hydratases from Rhodococcus rhodochrous J1. PLoS One, 12(6), e0179833.

Lee, B.S., Shin, S., Jeon, J.Y., Jang, K.-S., Lee, B.Y., Choi, S., Yoo, T.H. 2015. Incorporation of Unnatural Amino Acids in Response to the AGG Codon. ACS Chemical Biology, 10(7), 1648-1653.

Li, M.H.T., Ung, P.M.U., Zajkowski, J., Garneau-Tsodikova, S., Sherman, D.H. 2009. Automated genome mining for natural products. BMC Bioinformatics, 10(1), 185. 
Liao, X., Lin, W., Chen, N., Li, L., Huang, D., Zhong, B., Chen, L., Liang, S., Lin, Y. 2020. Overexpression of the regulatory subunit of protein kinase A increases heterologous protein expression in Pichia pastoris. Biotechnology letters.

Lin, L., Meng, X., Liu, P., Hong, Y., Wu, G., Huang, X., Li, C., Dong, J., Xiao, L., Liu, Z. 2009. Improved catalytic efficiency of Endo- $\beta$-1,4-glucanase from Bacillus subtilis BME-15 by directed evolution. Applied microbiology and biotechnology, 82(4), 671679.

Lin, X.-q., Liang, S.-1., Han, S.-y., Zheng, S.-p., Ye, Y.-r., Lin, Y. 2013. Quantitative iTRAQ LCâ€"MS/MS proteomics reveals the cellular response to heterologous protein overexpression and the regulation of HAC1 in Pichia pastoris. Journal of Proteomics, 91, 58-72.

Liu, H., Li, J., Du, G., Zhou, J., Chen, J. 2012a. Enhanced production of $\alpha$-cyclodextrin glycosyltransferase in Escherichia coli by systematic codon usage optimization. Journal of industrial microbiology \& biotechnology, 39(12), 1841-1849.

Liu, Q., Li, J., Gao, R., Li, J., Ma, G., Tian, C. 2019. CLR-4, a novel conserved transcription factor for cellulase gene expression in ascomycete fungi. Molecular Microbiology, 111(2), 373-394.

Liu, S., Wang, M., Du, G., Chen, J. 2016. Improving the active expression of transglutaminase in Streptomyces lividans by promoter engineering and codon optimization. BMC Biotechnology, 16(1), 75.

Liu, X., Wu, D., Wu, J., Chen, J. 2012b. Optimization of the production of Aspergillus niger $\alpha$-glucosidase expressed in Pichia pastoris. World journal of microbiology \& biotechnology, 29. 
Liu, Y., Zhang, T., Zhang, Z., Sun, T., Wang, J., Lu, F. 2014. Improvement of cold adaptation of Bacillus alcalophilus alkaline protease by directed evolution. Journal of Molecular Catalysis B: Enzymatic, 106, 117-123.

Llanes, B., McFall, E. 1969. Role of lac Genes in Induction of Beta-Galactosidase Synthesis by Galactose. Journal of Bacteriology, 97(1), 223-229.

Lorenz, P., Eck, J.r. 2005. Metagenomics and industrial applications. Nature Reviews Microbiology, 3(6), 510-516.

Lu, X., Chen, J., Jiao, L., Zhong, L., Lu, Z., Zhang, C., Lu, F. 2019. Improvement of the activity of 1-asparaginase I improvement of the catalytic activity of 1-asparaginase I from Bacillus megaterium $\mathrm{H}-1$ by in vitro directed evolution. Journal of Bioscience and Bioengineering, 128(6), 683-689.

Lv, X., Zheng, F., Li, C., Zhang, W., Chen, G., Liu, W. 2015. Characterization of a copper responsive promoter and its mediated overexpression of the xylanase regulator 1 results in an induction-independent production of cellulases in Trichoderma reesei. Biotechnology for biofuels, 8, 67-67.

Madhavan, A., Sindhu, R., Binod, P., Sukumaran, R.K., Pandey, A. 2017. Strategies for design of improved biocatalysts for industrial applications. Bioresource Technology, 245, 1304-1313.

Mahmoodi, M., Najafpour, G.D., Mohammadi, M. 2017. Production of pectinases for quality apple juice through fermentation of orange pomace. Journal of food science and technology, 54(12), 4123-4128.

Majeke, B.M., García-Aparicio, M., Biko, O.D., Viljoen-Bloom, M., van Zyl, W.H., Görgens, J.F. 2020. Synergistic codon optimization and bioreactor cultivation toward enhanced secretion of fungal lignin peroxidase in Pichia pastoris: Enzymatic valorization of technical (industrial) lignins. Enzyme and microbial technology, 139, 109593. 
Markel, U., Essani, K.D., Besirlioglu, V., Schiffels, J., Streit, W., Schwaneberg, U. 2019. Advances in ultrahigh-throughput screening for directed enzyme evolution. Chemical Society reviews.

Mayer, C., Dulson, C., Reddem, E., Thunnissen, A.-M.W.H., Roelfes, G. 2019. Directed Evolution of a Designer Enzyme Featuring an Unnatural Catalytic Amino Acid. Angewandte Chemie (International ed. in English), 58(7), 2083-2087.

Mirete, S., Morgante, V., Eduardo, G.-P.J. 2016. Functional metagenomics of extreme environments. Current Opinion in Biotechnology, 38, 143-149.

Moon, Y.-M., Yang, S.Y., Choi, T.R., Jung, H.-R., Song, H.-S., Han, Y.h., Park, H.Y., Bhatia, S.K., Gurav, R., Park, K., Kim, J.-S., Yang, Y.-H. 2019. Enhanced production of cadaverine by the addition of hexadecyltrimethylammonium bromide to whole cell system with regeneration of pyridoxal-5'-phosphate and ATP. Enzyme and microbial technology, 127, 58-64.

Moreno, A.D., Ibarra, D., Eugenio, M.E., Tomás-Pejó, E. 2020. Laccases as versatile enzymes: from industrial uses to novel applications. Journal of Chemical Technology \& Biotechnology, 95(3), 481-494.

Motahar, S.F.S., Khatibi, A., Salami, M., Ariaeenejad, S., Emam-Djomeh, Z., Nedaei, H., Kavousi, K., Sheykhabdolahzadeh Mamaghani, A., Salekdeh, G.H. 2020. A novel metagenome-derived thermostable and poultry feed compatible $\alpha$-amylase with enhanced biodegradation properties. International journal of biological macromolecules, 164, 2124-2133.

Nasseri, S.A., Betschart, L., Opaleva, D., Rahfeld, P., Withers, S.G. 2018. A Mechanism-Based Approach to Screening Metagenomic Libraries for Discovery of Unconventional Glycosidases. Angewandte Chemie International Edition, 57(35), 11359-11364. 
Nik-Pa, N.I.M., Sobri, M.F.M., Abd-Aziz, S., Ibrahim, M.F., Kamal Bahrin, E., Mohammed Alitheen, N.B., Ramli, N. 2020. Combined Optimization of Codon Usage and Glycine Supplementation Enhances the Extracellular Production of a $\beta$-Cyclodextrin Glycosyltransferase from Bacillus sp. NR5 UPM in Escherichia coli. International Journal of Molecular Sciences, 21(11), 3919.

Niu, J., Homan, T.G., Arentshorst, M., de Vries, R.P., Visser, J., Ram, A.F.J. 2015. The interaction of induction and repression mechanisms in the regulation of galacturonic acid-induced genes in Aspergillus niger. Fungal Genetics and Biology, 82, 32-42.

Noguchi, Y., Sano, M., Kanamaru, K., Ko, T., Takeuchi, M., Kato, M., Kobayashi, T. 2009. Genes regulated by AoXlnR, the xylanolytic and cellulolytic transcriptional regulator, in Aspergillus oryzae. Applied Microbiology and Biotechnology, 85(1), 141-154.

Nogueira, M., Enfissi, E.M.A., Welsch, R., Beyer, P., Zurbriggen, M.D., Fraser, P.D. 2019. Construction of a fusion enzyme for astaxanthin formation and its characterisation in microbial and plant hosts: A new tool for engineering ketocarotenoids. Metabolic Engineering, 52, 243-252.

Olson, D.G., Maloney, M., Lanahan, A.A., Hon, S., Hauser, L.J., Lynd, L.R. 2015. Identifying promoters for gene expression in Clostridium thermocellum. Metabolic Engineering Communications, 2, 23-29.

Orth, P., Schnappinger, D., Hillen, W., Saenger, W., Hinrichs, W. 2000. Structural basis of gene regulation by the tetracycline inducible Tet repressorâ€"operator system. Nature Structural Biology, 7(3), 215-219.

Østby, H., Hansen, L.D., Horn, S.J., Eijsink, V.G.H., Várnai, A. 2020. Enzymatic processing of lignocellulosic biomass: principles, recent advances and perspectives. Journal of Industrial Microbiology \& Biotechnology. 
Pan, X., Yu, Q., Chu, J., Jiang, T., He, B. 2018. Fitting replacement of signal peptide for highly efficient expression of three penicillin G acylases in E. coli. Applied Microbiology and Biotechnology, 102(17), 7455-7464.

Patel, A.K., Singhania, R.R., Sim, S.J., Pandey, A. 2019. Thermostable cellulases: Current status and perspectives. Bioresource Technology, 279, 385-392.

Patel, S.N., Kaushal, G., Singh, S.P. 2020. A Novel d-Allulose 3-Epimerase Gene from the Metagenome of a Thermal Aquatic Habitat and d-Allulose Production by Bacillus subtilis Whole-Cell Catalysis. Applied and Environmental Microbiology, 86(5).

Pessoa, T.B.A., Rezende, R.P., Marques, E.d.L.S., Pirovani, C.P., dos Santos, T.F., dos Santos Goncalves, A.C., Romano, C.C., Dotivo, N.C., Freitas, A.C.O., Salay, L.C., Dias, J.C.T. 2017. Metagenomic alkaline protease from mangrove sediment. Journal of Basic Microbiology, 57(11), 962-973.

Prayogo, F.A., Budiharjo, A., Kusumaningrum, H.P., Wijanarka, W., Suprihadi, A., Nurhayati, N. 2020. Metagenomic applications in exploration and development of novel enzymes from nature: a review. Journal of Genetic Engineering and Biotechnology, 18(1), 39.

Qin, X., Qian, J., Yao, G., Zhuang, Y., Zhang, S., Chu, J. 2011. GAP promoter library for finetuning of gene expression in Pichia pastoris. Applied and Environmental Microbiology, 77(11), 3600-3608.

Qiu, J., Yang, H., Yan, Z., Shi, Y., Zou, D., Ding, L., Shao, Y., Li, L., Khan, U., Sun, S., Xin, Z. 2020. Characterization of XtjR8: A novel esterase with phthalate-hydrolyzing activity from a metagenomic library of lotus pond sludge. International journal of biological macromolecules, 164, 1510-1518.

Rajesh, R.O., Godan, T.K., Rai, A.K., Sahoo, D., Pandey, A., Binod, P. 2019. Biosynthesis of 2,5-furan dicarboxylic acid by Aspergillus flavus APLS-1: Process optimization and intermediate product analysis. Bioresource Technology, 284, 155-160. 
Ran, T., Saleem, A.M., Shen, Y., Ribeiro, G.O., Jr, Beauchemin, K.A., Tsang, A., Yang, W., McAllister, T.A. 2019. Effects of a recombinant fibrolytic enzyme on fiber digestion, ruminal fermentation, nitrogen balance, and total tract digestibility of heifers fed a high forage diet1. Journal of Animal Science, 97(8), 3578-3587.

Raveendran, S., Parameswaran, B., Ummalyma, S.B., Abraham, A., Mathew, A.K., Madhavan, A., Rebello, S., Pandey, A. 2018. Applications of Microbial Enzymes in Food Industry. Food technology and biotechnology, 56(1), 16-30.

Saha, P., Khan, M.F., Patra, S. 2018. Truncated $\alpha$-amylase: an improved candidate for textile processing. Preparative biochemistry \&amp; biotechnology, 48(7), 635-645.

Sanchez-Reyez, A., Batista-Garca, R.A., Valdes-Garcia, G., Ortiz, E., Perezgasga, L., ZarateRomero, A., Pastor, N., Folch-Mallol, J.L. 2017. A family 13 thioesterase isolated from an activated sludge metagenome: Insights into aromatic compounds metabolism. Proteins: Structure, Function, and Bioinformatics, 85(7), 1222-1237.

Savile, C.K., Janey, J.M., Mundorff, E.C., Moore, J.C., Tam, S., Jarvis, W.R., Colbeck, J.C., Krebber, A., Fleitz, F.J., Brands, J., Devine, P.N., Huisman, G.W., Hughes, G.J. 2010. Biocatalytic Asymmetric Synthesis of Chiral Amines from Ketones Applied to Sitagliptin Manufacture. Science, 329(5989), 305.

Şen, A., Kargar, K., Akgün, E., Pinar, M.Ç. 2020. Codon Optimization: A Mathematical Programming Approach. Bioinformatics.

Shakya, M., Lo, C.-C., Chain, P.S.G. 2019. Advances and Challenges in Metatranscriptomic Analysis. Frontiers in Genetics, 10(904).

Sharma, A., Gupta, G., Ahmad, T., Mansoor, S., Kaur, B. 2019. Enzyme Engineering: Current trends and future perspectives. Food Reviews International, 1-34.

Sharma, H.P., Patel, H., Sugandha. 2017. Enzymatic added extraction and clarification of fruit juices-A review. Critical reviews in food science and nutrition, 57(6), 1215-1227. 
Sheldon, R.A., Pereira, P.C. 2017. Biocatalysis engineering: the big picture. Chemical Society reviews, 46(10), 2678-2691.

Singh, R., Upadhyay, S., Singh, M., Sharma, I., Sharma, P., Kamboj, P., Saini, A., Voraha, R., Sharma, A., Upadhyay, T., Khan, F. 2020a. Chitin, Chitinases and Chitin Derivatives in Biopharmaceutical, Agricultural and Environmental Perspective. Biointerface Research in Applied Chemistry, 11, 9985-10005.

Singh, S., Dhillon, A., Goyal, A. 2020b. Enhanced catalytic efficiency of Bacillus amyloliquefaciens SS35 endoglucanase by ultraviolet directed evolution and mutation analysis. Renewable Energy, 151, 1124-1133.

Smith, M.R., Khera, E., Wen, F. 2015. Engineering Novel and Improved Biocatalysts by Cell Surface Display. Industrial \& Engineering Chemistry Research, 54(16), 4021-4032.

Sooksai, T., Bankeeree, W., Sangwatanaroj, U., Lotrakul, P., Punnapayak, H., Prasongsuk, S. 2019. Production of cutinase from Fusarium falciforme and its application for hydrophilicity improvement of polyethylene terephthalate fabric. 3 Biotech, 9(11), 389.

Speda, J., Jonsson, B.-H., Carlsson, U., Karlsson, M. 2017. Metaproteomics-guided selection of targeted enzymes for bioprospecting of mixed microbial communities. Biotechnology for biofuels, 10, 128-128.

Srivastava, A., Summers, M.L., Sobotka, R. 2020. Cyanobacterial sigma factors: Current and future applications for biotechnological advances. Biotechnology Advances, 40, 107517.

Tang, L., Xia, Y., Wu, X., Chen, X., Zhang, X., Li, H. 2017. Screening and characterization of a novel thermostable lipase with detergent-additive potential from the metagenomic library of a mangrove soil. Gene, $\mathbf{6 2 5}, 64-71$. 
Thapa, S., Li, H., Ohair, J., Bhatti, S., Chen, F.-C., Nasr, K.A., Johnson, T., Zhou, S. 2019. Biochemical Characteristics of Microbial Enzymes and Their Significance from Industrial Perspectives. Molecular Biotechnology, 61(8), 579-601.

Thiel, K., Mulaku, E., Dandapani, H., Nagy, C., Aro, E.-M., Kallio, P. 2018. Translation efficiency of heterologous proteins is significantly affected by the genetic context of RBS sequences in engineered cyanobacterium Synechocystis sp. PCC 6803. Microbial Cell Factories, 17(1), 34.

Thimoteo, S.S., Glogauer, A., Faoro, H., de Souza, E.M., Huergo, L.F., Moerschbacher, B.M., Pedrosa, F.O. 2017. A broad $\mathrm{pH}$ range and processive chitinase from a metagenome library. Brazilian journal of medical and biological research $=$ Revista brasileira de pesquisas medicas e biologicas, 50(1), e5658-e5658.

Tian, B., Chen, Y., Ding, S. 2012. A combined approach for improving alkaline acetyl xylan esterase production in Pichia pastoris, and effects of glycosylation on enzyme secretion, activity and stability. Protein Expression and Purification, 85(1), 44-50.

Tiwari, R., Nain, L., Labrou, N.E., Shukla, P. 2018. Bioprospecting of functional cellulases from metagenome for second generation biofuel production: a review. Critical Reviews in Microbiology, 44(2), 244-257.

Ucar, E.Y. 2019. Update on Thrombolytic Therapy in Acute Pulmonary Thromboembolism. The Eurasian journal of medicine, 51(2), 186-190.

Vagstad, A.L., Kuranaga, T., Püntener, S., Pattabiraman, V.R., Bode, J.W., Piel, J. 2019. Introduction of d-Amino Acids in Minimalistic Peptide Substrates by an S-Adenosyl1-Methionine Radical Epimerase. Angewandte Chemie International Edition, 58(8), 2246-2250.

Vidmar, B., Vodovnik, M. 2018. Microbial Keratinases: Enzymes with Promising Biotechnological Applications. Food technology and biotechnology, 56(3), 312-328. 
Wang, J., Lu, L., Feng, F. 2017. Combined strategies for improving production of a thermoalkali stable laccase in Pichia pastoris. Electronic Journal of Biotechnology, 28, 7-13.

Wang, L., Yao, J., Niu, J., Liu, J., Li, B., Feng, M. 2018. Eco-friendly and highly efficient enzyme-based wool shrinkproofing finishing by multiple padding techniques. Polymers, 10(11), 1213.

Wang, S., Meng, X., Zhou, H., Liu, Y., Secundo, F., Liu, Y. 2016. Enzyme stability and activity in non-aqueous reaction systems: a mini review. Catalysts, 6(2), 32.

Wang, W., Li, X., Wang, J., Xiang, S., Feng, X., Yang, K. 2013. An Engineered Strong Promoter for Streptomycetes. Applied and Environmental Microbiology, 79(14), 44844492.

Wang, X., Sun, Y., Ke, F., Zhao, H., Liu, T., Xu, L., Liu, Y., Yan, Y. 2012. Constitutive Expression of Yarrowia lipolytica Lipase LIP2 in Pichia pastoris Using GAP as Promoter. Applied Biochemistry and Biotechnology, 166(5), 1355-1367.

Xu, X., Liu, M.-q., Huo, W.-k., Dai, X.-j. 2016. Obtaining a mutant of Bacillus amyloliquefaciens xylanase A with improved catalytic activity by directed evolution. Enzyme and microbial technology, 86, 59-66.

Yang, J.-L., Li, X.-L., Jiang, F.-L., Gong, T., Chen, J.-J., Chen, T.-J., Zhu, P. 2020. High-level soluble expression of human $\mathrm{Cu}, \mathrm{Zn}$ superoxide dismutase with high activity in Escherichia coli. World Journal of Microbiology and Biotechnology, 36(7), 106.

Yin, Q., Zhou, G., Peng, C., Zhang, Y., Kües, U., Liu, J., Xiao, Y., Fang, Z. 2019. The first fungal laccase with an alkaline $\mathrm{pH}$ optimum obtained by directed evolution and its application in indigo dye decolorization. AMB Express, 9(1), 151.

Zhang, A.-L., Luo, J.-X., Zhang, T.-Y., Pan, Y.-W., Tan, Y.-H., Fu, C.-Y., Tu, F.-z. 2009. Recent advances on the GAP promoter derived expression system of Pichia pastoris. Molecular Biology Reports, 36(6), 1611-1619. 
Zhang, B., Wan, F., Qiu, Y.L., Chen, X.L., Tang, L., Chen, J.C., Xiong, Y.H. 2015. Increased L-arginine Production by Site-directed Mutagenesis of N-acetyl-L-glutamate Kinase and proB Gene Deletion in Corynebacterium crenatum. Biomedical and Environmental Sciences, 28(12), 864-874.

Zhang, Y., Wang, Q., Hess, H. 2017. Increasing Enzyme Cascade Throughput by pHEngineering the Microenvironment of Individual Enzymes. ACS Catalysis, 7(3), 20472051.

Zheng, X., Zhang, Y., Zhang, X., Li, C., Liu, X., Lin, Y., Liang, S. 2019. Fhl1p protein, a positive transcription factor in Pichia pastoris, enhances the expression of recombinant proteins. Microbial Cell Factories, 18(1), 207.

Zhou, J., Liu, H., Du, G., Li, J., Chen, J. 2012. Production of $\alpha$-Cyclodextrin Glycosyltransferase in Bacillus megaterium MS941 by Systematic Codon Usage Optimization. Journal of agricultural and food chemistry, 60(41), 10285-10292.

Zhou, J., Zhu, P., Hu, X., Lu, H., Yu, Y. 2018. Improved secretory expression of lignocellulolytic enzymes in Kluyveromyces marxianus by promoter and signal sequence engineering. Biotechnology for biofuels, 11(1), 235. 


\section{Figures caption}

Figure 1a: Illustration of enzyme engineering through directed evolution (A) and site directed mutagenesis (B).

Figure 1b: Illustration of fusion of multiple proteins using linker proteins.

Figure 1c: Illustration of enzyme engineering through incorporation of unnatural amino acids; (A) native peptide synthesis, (B) Re-assigning of rare t-RNA molecule of natural aminoacid to unnatural aminoacid, and (C) Re-assigning of stop codon to unnatural aminoacid.

Figure 1d: Illustration of enzyme engineering through surface display technology. E1-E3: three enzymes catalysing a process to convert substrate to end product. 
Table. 1 Industrial application of various enzymes

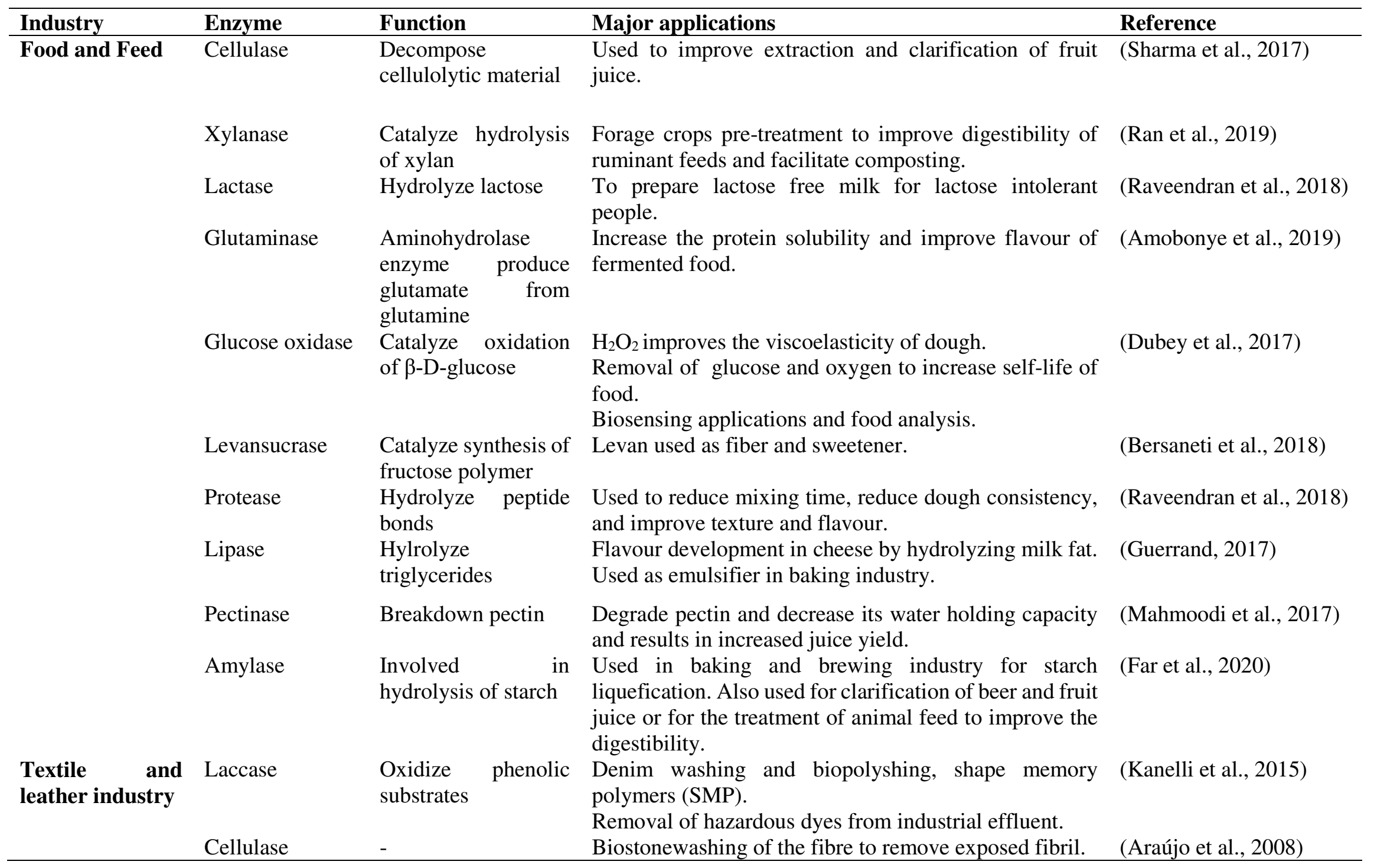




\begin{tabular}{|c|c|c|c|c|}
\hline & Amylase & - & For efficient desizing without affecting fabric. & (Saha et al., 2018) \\
\hline & Lipase & - & Degreasing of fat from animal skin during processing. & (Chandra et al., 2020) \\
\hline & Savinase & $\begin{array}{l}\text { Type of protease } \\
\text { hydrolyze peptide } \\
\text { bonds }\end{array}$ & Treatment of wool fibers for shrinkproof finishing. & (Wang et al., 2018) \\
\hline & Cutinase & $\begin{array}{l}\text { Belongs to serine } \\
\text { esterase and break } \\
\text { down ester bond }\end{array}$ & $\begin{array}{l}\text { Used in the modification of PET fiber to improve } \\
\text { hydrophilicity. }\end{array}$ & (Sooksai et al., 2019) \\
\hline & $\begin{array}{l}\text { Transglutaminas } \\
\text { e }\end{array}$ & - & $\begin{array}{l}\text { Cross linking leather proteins with filler (glucose, flour } \\
\text { and gum) to provide smooth surface. }\end{array}$ & (Duarte et al., 2020) \\
\hline & Keratinase & $\begin{array}{lr}\text { Type of } & \text { serine } \\
\text { protease } & \text { and } \\
\text { hydrolyze } & \text { peptide } \\
\text { bond } & \end{array}$ & Removal of hairs during the leather processing. & $\begin{array}{l}\text { (Vidmar \& Vodovnik, } \\
\text { 2018) }\end{array}$ \\
\hline \multirow[t]{4}{*}{ Cosmetics } & $\begin{array}{l}\text { Superoxide } \\
\text { dismutase }\end{array}$ & $\begin{array}{l}\text { Dismutation of } \\
\text { superoxide radicals }\end{array}$ & $\begin{array}{l}\text { To mitigate the effect of reactive oxygen species (ROS) } \\
\text { in antiaging cream. }\end{array}$ & (Gomes et al., 2020) \\
\hline & Protease & - & Exfoliation of dead skin. & (Gomes et al., 2020) \\
\hline & Photolyases & $\begin{array}{l}\text { Eliminate thymine } \\
\text { dimer }\end{array}$ & Reversal of sun damage to skin. & (Gomes et al., 2020) \\
\hline & $\begin{array}{l}\text { Oxidase, } \\
\text { peroxidase }\end{array}$ & $\begin{array}{l}\text { Catalyze oxidation- } \\
\text { reduction reaction }\end{array}$ & Used in hair dying products. & (Hirose, 2017) \\
\hline \multirow[t]{6}{*}{ Bioenergy } & Cellulase & - & Hydrolyze cellulose into fermentable sugars. & (Huang et al., 2018) \\
\hline & Xylanase & - & $\begin{array}{l}\text { Xylanase degrade xylan and increase accessibility of } \\
\text { cellulase to cellulose. }\end{array}$ & \\
\hline & Laccase & - & $\begin{array}{l}\text { Have role in lignin degradation and detoxification of } \\
\text { various aromatic compounds which results in increased } \\
\text { fermentation. }\end{array}$ & (Bhatia et al., 2020b) \\
\hline & Lipase & $\begin{array}{l}\text { Catalyze } \\
\text { esterification and } \\
\text { transesterification }\end{array}$ & $\begin{array}{l}\text { Transesterification of oil with alcohols to produce } \\
\text { biodiesel. }\end{array}$ & (Bhatia et al., 2017) \\
\hline & $\begin{array}{l}\text { Fatty acid } \\
\text { decarboxylase }\end{array}$ & $\begin{array}{l}\text { Catalyze } \\
\text { decarboxylation }\end{array}$ & Used for the decarboxylation of fatty acids into alkene. & (Jiang et al., 2019) \\
\hline & $\begin{array}{l}\text { Carbonic } \\
\text { anhydrase }\end{array}$ & $\begin{array}{l}\text { Interconversion of } \\
\mathrm{CO}_{2} \text { and } \mathrm{H}_{2} \mathrm{O} \text { into } \\
\text { carbonic acid }\end{array}$ & Capturing carbon dioxide for bioenergy production. & (Bhatia et al., 2019) \\
\hline
\end{tabular}




\begin{tabular}{|c|c|c|c|c|}
\hline \multirow[t]{5}{*}{$\begin{array}{l}\text { Biochemical } \\
\text { Production }\end{array}$} & $\begin{array}{l}\text { Lysine } \\
\text { decarboxylase }\end{array}$ & $\begin{array}{l}\text { Catalyze } \\
\text { decarboxylation } \\
\text { reaction }\end{array}$ & $\begin{array}{l}\text { Conversion of lysin into cadaverine a precursor for } \\
\text { nylon } 66 .\end{array}$ & (Moon et al., 2019) \\
\hline & $\begin{array}{l}\text { Lysine } \\
\text { decyclodeamina } \\
\text { se }\end{array}$ & $\begin{array}{l}\text { Catalyze } \\
\text { deamination reaction }\end{array}$ & Used in biotransformation of lysine into pipecolic acid. & (Han et al., 2020) \\
\hline & Lipase & - & Used in synthesis of commercially important esters. & (Chandra et al., 2020) \\
\hline & $\begin{array}{l}\text { Arylacetonitrilas } \\
\mathrm{e}\end{array}$ & $\begin{array}{l}\text { Catalyze } \\
\text { deamination reaction }\end{array}$ & $\begin{array}{l}\text { Reported for production of acids from their } \\
\text { corresponding arylacetonitriles. }\end{array}$ & (Bhatia et al., 2014) \\
\hline & Epimerase & Epimerization & $\begin{array}{l}\text { D-allulose 3-epimerase was used for D-fructose } \\
\text { conversion into D-allulose }\end{array}$ & (Patel et al., 2020) \\
\hline \multirow[t]{5}{*}{ Pharmaceuticals } & Chitinase & - & $\begin{array}{l}\text { Used in the treatment of inflammatory or fibrotic } \\
\text { diseases. }\end{array}$ & (Singh et al., 2020a) \\
\hline & Nattokinase & - & $\begin{array}{l}\text { It has fibrinolytic activity, lipid-lowering, and } \\
\text { neuroprotective effects. }\end{array}$ & (Chen et al., 2018) \\
\hline & Lipase & - & $\begin{array}{l}\text { Catalyze the resolution of enantiomeric pharmaceutical } \\
\text { s or drug precursors } \\
\text { (ibuprofen, ketoprofen and atenolol etc.). }\end{array}$ & (Contesini et al., 2012) \\
\hline & L-asparaginase & $\begin{array}{l}\text { Hydrolyze } \\
\text { asparagine }\end{array}$ & Used in the treatment of acute lymphoblastic leukaemia. & (Brumano et al., 2019) \\
\hline & Streptokinase & $\begin{array}{l}\text { Promote lysis of } \\
\text { Arg/Val bond in } \\
\text { plasminogen }\end{array}$ & $\begin{array}{l}\text { Used in the brake down of clot in case of myocardial } \\
\text { infarction. }\end{array}$ & (Ucar, 2019) \\
\hline \multirow[t]{5}{*}{$\begin{array}{l}\text { Detergent } \\
\text { industry }\end{array}$} & Lipase & - & $\begin{array}{l}\text { Decompose fatty materials that are major components of } \\
\text { oil related stain. }\end{array}$ & (Kumari et al., 2019) \\
\hline & Cellulase & - & Used to improve colour brightness and fabric softening & (Patel et al., 2019) \\
\hline & Amylase & - & $\begin{array}{l}\text { Act on stains contains starch by degrading starch into } \\
\text { short sugars. }\end{array}$ & \\
\hline & Laccase & - & Used in cloth washing to remove the odor from fabric. & (Moreno et al., 2020) \\
\hline & Mannase & Degrade mannan & Used for mannan stain removal. & $\begin{array}{l}\text { (Al-Ghanayem \& Joseph, } \\
\text { 2020) }\end{array}$ \\
\hline
\end{tabular}


Table. 2 Improved production of enzymes by codon optimization

\begin{tabular}{|c|c|c|c|c|c|}
\hline Host & Gene origin & Enzyme & Comment & Activity/Improvement & Reference \\
\hline $\begin{array}{l}\text { Bacillus } \\
\text { megaterium }\end{array}$ & $\begin{array}{l}\text { Paenibacillus } \\
\text { macerans }\end{array}$ & $\begin{array}{l}\alpha-C y c l o d e x t r i n \\
\text { glycosyltransferase }\end{array}$ & $\begin{array}{l}\text { To ensure protein expression and } \\
\text { secretion of enzyme a strong } \\
\text { inducible promoter Pxyl and the } \\
\text { signal peptide SPLipA was used. }\end{array}$ & $48.9 \mathrm{U} / \mathrm{ml}$ & (Zhou et al., 2012) \\
\hline \multirow[t]{6}{*}{ E. coli } & $\begin{array}{l}\text { Bacillus sp. NR5 } \\
\text { UPM }\end{array}$ & $\begin{array}{l}\beta \text {-Cyclodextrin } \\
\text { glycosyltransferase }\end{array}$ & $\begin{array}{l}\text { Codon optimization and } \\
\text { supplementation of glycine } \\
\text { resulted in increased secretion and } \\
\text { improved activity. }\end{array}$ & 2.2 fold & $\begin{array}{l}\text { (Nik-Pa et al., } \\
2020)\end{array}$ \\
\hline & $\begin{array}{l}\text { Paenibacillus } \\
\text { macerans JFB05- } \\
01\end{array}$ & $\begin{array}{l}\alpha-C y c l o d e x t r i n \\
\text { glycosyltransferase }\end{array}$ & $\begin{array}{l}\text { Total protein yield and } \\
\text { extracellular enzyme activity } \\
\text { improved. }\end{array}$ & $326 \%$ & (Liu et al., 2012a) \\
\hline & $\begin{array}{l}\text { Candida } \\
\text { antarctica }\end{array}$ & Lipase B & $\begin{array}{l}\text { Molecular dynamic simulation, } \\
\text { codon optimization and statistical } \\
\text { analysis approach was used. }\end{array}$ & 2.1 fold & $\begin{array}{l}\text { (Ghahremanifard } \\
\text { et al., 2018) }\end{array}$ \\
\hline & Human & Superoxide dismutase & $\begin{array}{l}\text { Codon optimization followed by } \\
\text { fed batch fermentation. }\end{array}$ & $46541 \mathrm{U} / \mathrm{mg}$ & (Yang et al., 2020) \\
\hline & $\begin{array}{l}\text { Rhodococcus } \\
\text { rhodochrous } \mathrm{J} 1\end{array}$ & $\begin{array}{l}\text { Nitrile hydratase } \\
\text { (NHase) }\end{array}$ & $\begin{array}{l}\text { High activity and shorter culture } \\
\text { time were achieved. }\end{array}$ & $\begin{array}{l}\text { L-Nhase }=400 \mathrm{U} / \mathrm{mg} \\
\mathrm{H}-\text { Nhase }=234 \mathrm{U} / \mathrm{mg}\end{array}$ & (Lan et al., 2017) \\
\hline & $\begin{array}{l}\text { Thermococcus } \\
\text { litoralis }\end{array}$ & Steryl glucosidase & $\begin{array}{l}\text { Promoter optimization, co } \\
\text { expression of chaperones with } \\
\text { development of high cell density } \\
\text { fermentation. }\end{array}$ & 200 fold & $\begin{array}{l}\text { (Eberhardt et al., } \\
\text { 2017) }\end{array}$ \\
\hline $\begin{array}{l}\text { Saccharomyces } \\
\text { cerevisiae }\end{array}$ & $\begin{array}{l}\text { Aspergillus } \\
\text { awamori }\end{array}$ & Glucoamylase & - & $31-40 \%$ & $\begin{array}{l}\text { (Favaro et al., } \\
\text { 2012) }\end{array}$ \\
\hline $\begin{array}{l}\text { Streptomyces } \\
\text { lividans }\end{array}$ & $\begin{array}{l}\text { Streptomyces } \\
\text { hygroscopicus }\end{array}$ & Transglutaminase & $\begin{array}{l}\text { Codon optimization coupled with } \\
\text { negative element removal from } \\
\text { promoter results in improved } \\
\text { enzyme yield. }\end{array}$ & $5.73 \mathrm{U} / \mathrm{ml}$ & (Liu et al., 2016) \\
\hline
\end{tabular}




\begin{tabular}{|c|c|c|c|c|c|}
\hline \multirow[t]{5}{*}{ Pichia pastoris } & Aspergillus niger & Endopolygalacturonase & $\begin{array}{l}\text { A combination of codon and } \\
\text { promoter optimization strategy } \\
\text { was used. }\end{array}$ & 1.19 fold & $\begin{array}{l}\text { (Karaoğlan \& } \\
\text { Erden-Karaoğlan, } \\
\text { 2020) }\end{array}$ \\
\hline & Aspergillus niger & $\alpha$-glucosidase & $\begin{array}{l}\text { Codon optimization leads to } \\
\text { enhanced translation efficiency } \\
\text { and stable mRNA structure. }\end{array}$ & & (Liu et al., 2012b) \\
\hline & $\begin{array}{l}\text { Bacillus } \\
\text { licheniformis LS04 }\end{array}$ & Laccase & $\begin{array}{l}\text { Combination of strategies; site } \\
\text { directed mutagenesis and } \\
\text { optimization of culture conditions } \\
\text { were used. }\end{array}$ & 9.3 fold & $\begin{array}{l}\text { (Wang et al., } \\
\text { 2017) }\end{array}$ \\
\hline & $\begin{array}{l}\text { Phanerochaete } \\
\text { chrysosporium }\end{array}$ & Lignin peroxidase & $\begin{array}{l}\text { Codon optimization followed by } \\
\text { fed batch fermentation } \\
\text { optimization. }\end{array}$ & $4480 \mathrm{U} / \mathrm{ml}$ & $\begin{array}{l}\text { (Majeke et al., } \\
\text { 2020) }\end{array}$ \\
\hline & $\begin{array}{l}\text { Starmerella } \\
\text { bombicola }\end{array}$ & Lactone esterase & $\begin{array}{l}\text { Codon optimization followed by } \\
\text { temperature optimization and } \\
\text { coexpression of transcription } \\
\text { factor } H A C l \text {. }\end{array}$ & 32 fold & $\begin{array}{l}\text { (De Waele et al., } \\
\text { 2018) }\end{array}$ \\
\hline
\end{tabular}


Table. 3 Improved activity and performance of the enzymes by directed evolution.

\begin{tabular}{|c|c|c|c|c|c|}
\hline Enzyme & Microorganism & Technique & Property modified & Improvement & Reference \\
\hline $\begin{array}{l}\text { Endo- } \beta-1,4- \\
\text { glucanase (Cel5A) }\end{array}$ & Bacillus subtilis & $\begin{array}{l}\text { Error-prone } \\
\text { polymerase chain } \\
\text { reaction (PCR) and } \\
\text { DNA shuffling }\end{array}$ & Mutations at V74A and D272G & $\begin{array}{l}\text { Improved } \mathrm{pH} \text { tolerance and } \\
\text { thermostability }\end{array}$ & (Lin et al., 2009) \\
\hline Xylanase & $\begin{array}{l}\text { Bacillus } \\
\text { amyloliquefaciens }\end{array}$ & $\begin{array}{l}\text { Error-prone } \\
\text { touchdown PCR }\end{array}$ & Point mutation S138T & $\begin{array}{l}3.5 \text { times improved specific } \\
\text { activity }\end{array}$ & (Xu et al., 2016) \\
\hline Protease & $\begin{array}{l}\text { Bacillus } \\
\text { alcalophilus }\end{array}$ & $\begin{array}{l}\text { Error-prone } \\
\text { polymerase chain } \\
\text { reaction }(\mathrm{PCR})\end{array}$ & Mutants E110A and E134A & 3.6 times increased in activity & (Liu et al., 2014) \\
\hline Lipase & Bacillus pumilus & DNA shuffling & $\begin{array}{l}\text { Three-point mutations G14S, A15G, } \\
\text { and V109S }\end{array}$ & $\begin{array}{l}8 \text { times improved activity and } 9 \\
\text { times longer half life }\end{array}$ & (Akbulut et al., 2013) \\
\hline Amylase & Bacillus sp. TS-25 & $\begin{array}{l}\text { Error-prone } \\
\text { polymerase chain } \\
\text { reaction (PCR) and } \\
\text { DNA shuffling }\end{array}$ & A point mutation $\mathrm{T} 142 \mathrm{~A}$ & $\begin{array}{l}20 \% \text { increase in activity, and } 50 \% \\
\text { increase in thermal stability }\end{array}$ & (Jones et al., 2008) \\
\hline Laccase & $\begin{array}{l}\text { Coprinopsis } \\
\text { cinereal }\end{array}$ & $\begin{array}{l}\text { Error-prone } \\
\text { polymerase chain } \\
\text { reaction }(\mathrm{PCR})\end{array}$ & $\begin{array}{l}\text { Three amino acid changes E116K, } \\
\text { N229D, I393T }\end{array}$ & $\begin{array}{l}\text { Improved } \mathrm{pH} \text { stability (in alkaline } \\
\text { conditions) }\end{array}$ & (Yin et al., 2019) \\
\hline $\begin{array}{l}\text { Carboxy methyl } \\
\text { cellulase }\end{array}$ & $\begin{array}{l}\text { Bacillus } \\
\text { amyloliquefaciens } \\
\text { SS35 }\end{array}$ & UV Irradiation & $\begin{array}{l}\text { Aspartate } 233 \text { was substituted by } \\
\text { glycine in CMCase-UV2 }\end{array}$ & $\begin{array}{l}1.6-4.1 \text {-fold increased activity } \\
\text { and enhanced } \mathrm{pH} \text { stability }\end{array}$ & (Singh et al., 2020a) \\
\hline $\begin{array}{l}\text { Cellobiohydrolase } \\
\text { Cel7A }\end{array}$ & Hypocrea jecorina & $\begin{array}{l}\text { Directed evolution } \\
\text { and genome shuffling }\end{array}$ & - & $\begin{array}{l}\text { Improved thermal stability and } 44- \\
\text { fold greater half life }\end{array}$ & (Goedegebuur et al., 2017) \\
\hline L-asparaginase & $\begin{array}{l}\text { Bacillus } \\
\text { megaterium } \mathrm{H}-1\end{array}$ & $\begin{array}{l}\text { Error-prone } \\
\text { polymerase chain } \\
\text { reaction (PCR) and } \\
\text { DNA shuffling }\end{array}$ & $\begin{array}{l}\text { Reduction of hydrogen bonds, and } \\
\text { incorporation of flexible residues at } \\
\text { an active site Thr } 15\end{array}$ & $\begin{array}{l}\sim 21 \text { fold improvement in catalytic } \\
\text { activity, tolerance wider } \mathrm{pH} \text { range } \\
\text { and temperatures }\end{array}$ & (Lu et al., 2019) \\
\hline
\end{tabular}


Fig. 1a

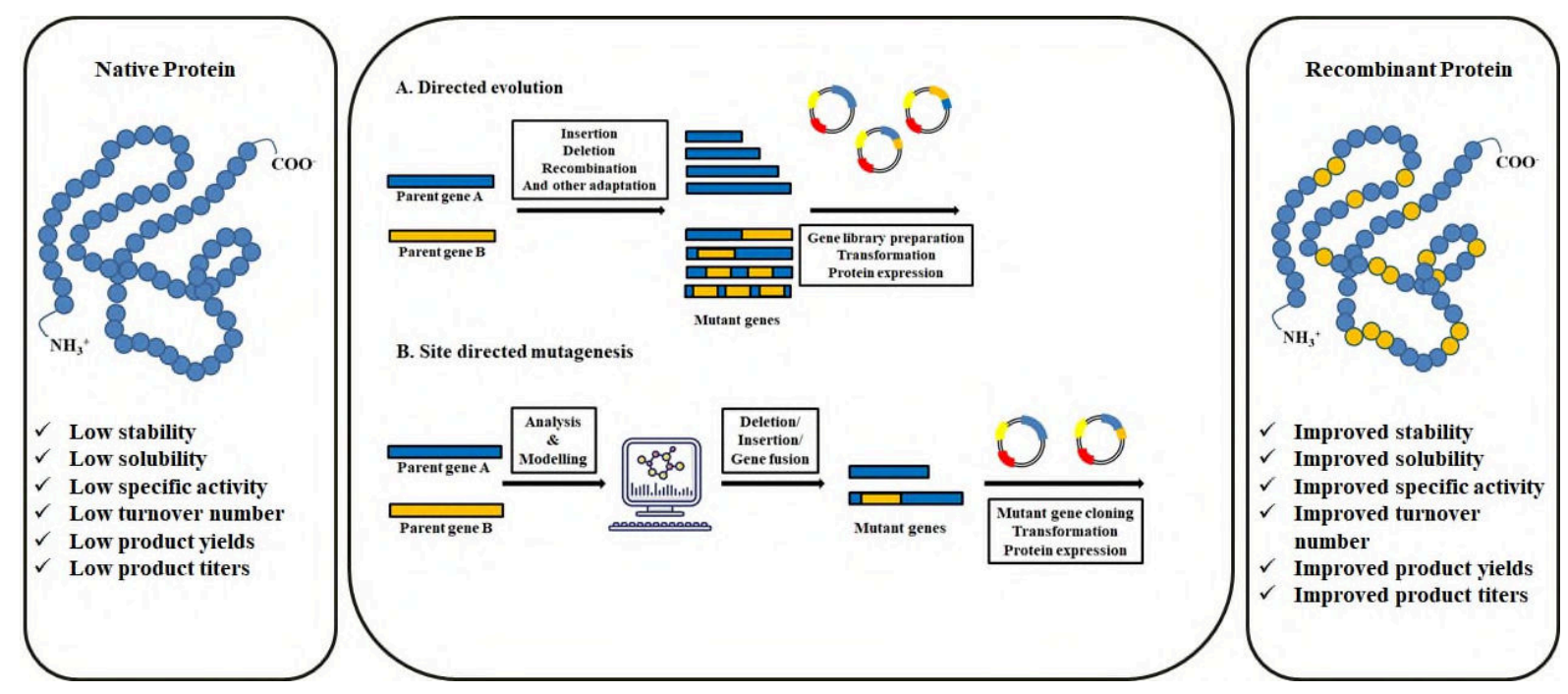

Fig. 1b

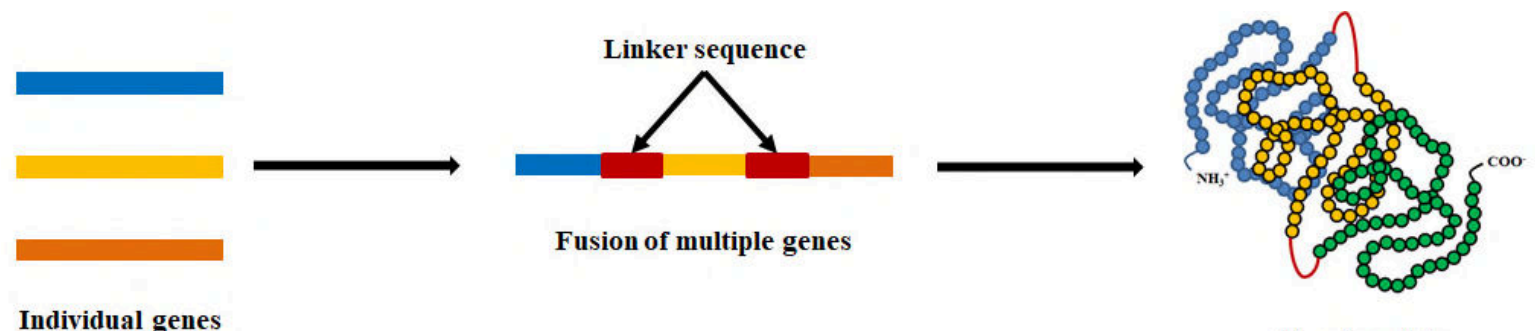

Individual genes

Fused protein 
Fig. 1c

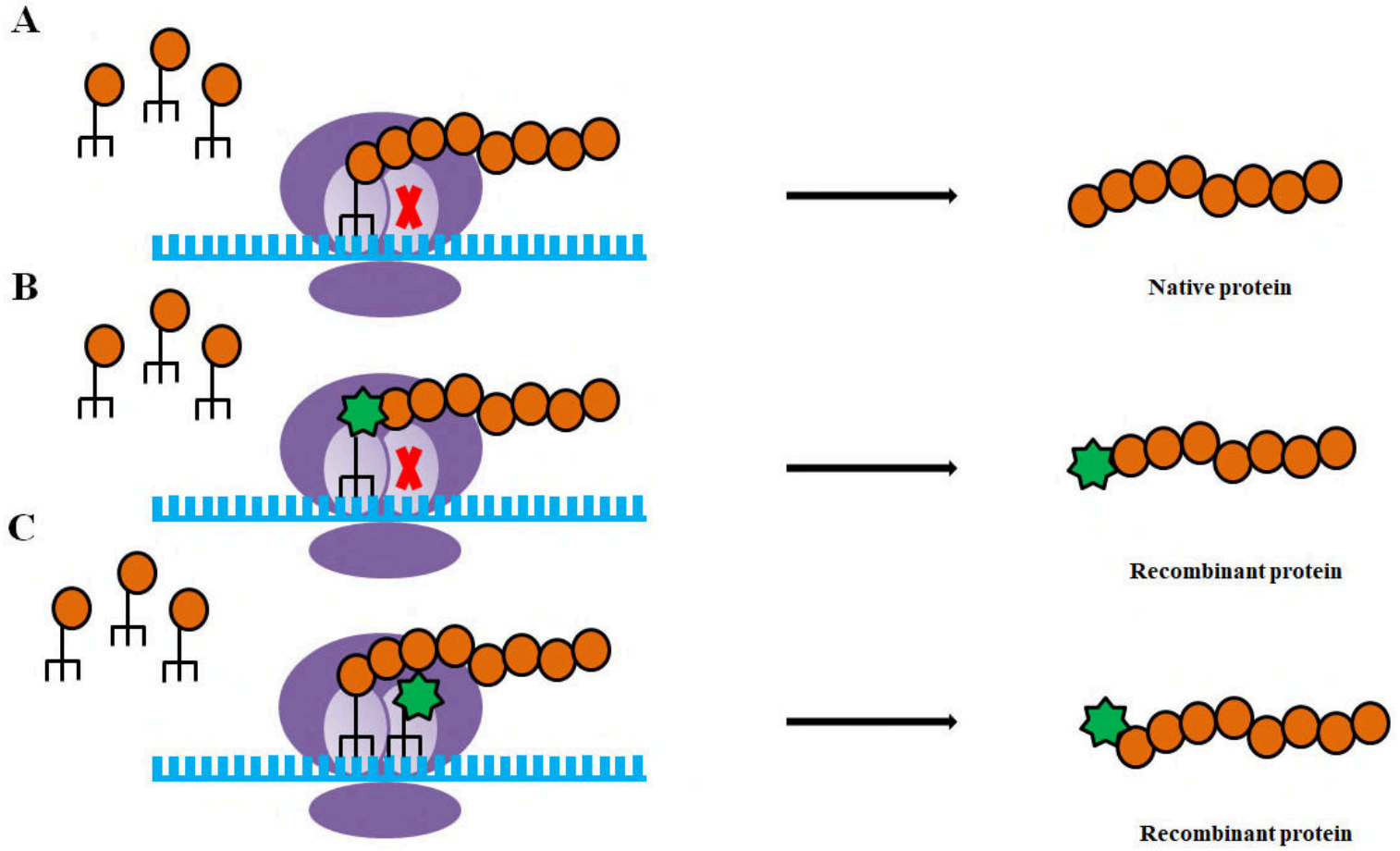

Fig. 1d

A

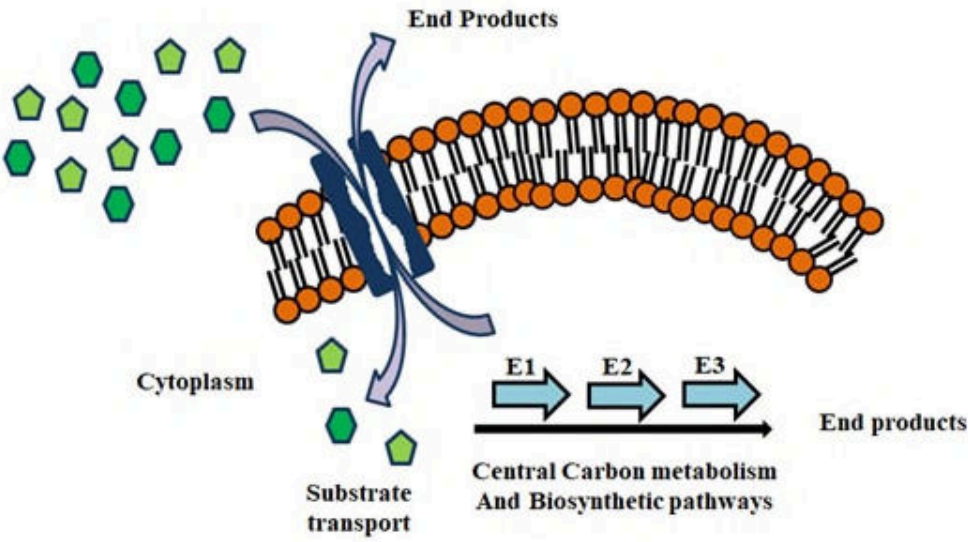

B

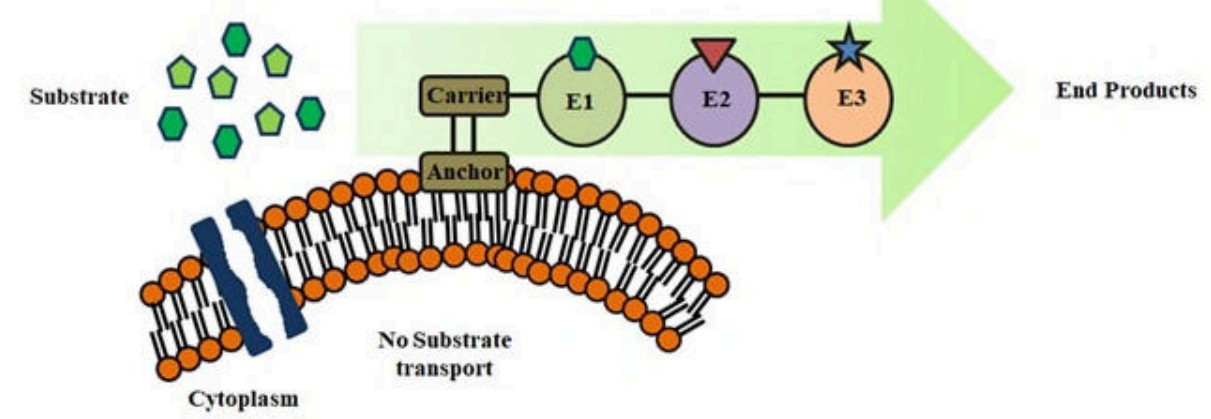

